\title{
First records, rediscovery and compilation of deep-sea echinoderms in the middle and lower continental slope of the Mediterranean Sea
}

\author{
Ariadna Mecho ${ }^{1}$, David S.M. Billett ${ }^{2}$, Eva Ramírez-Llodra ${ }^{3}$, Jacopo Aguzzi ${ }^{1}$, Paul A. Tyler ${ }^{4}$, \\ Joan B. Company ${ }^{1}$ \\ ${ }^{1}$ Institut de Ciències del Mar, CSIC, Passeig Marítim de la Barceloneta, 37-49, 08003 Barcelona, Spain. \\ E-mail: mecho@icm.csic.es \\ ${ }^{2}$ National Oceanography Centre, University of Southampton Waterfront Campus, European Way, \\ Southampton SO14 3ZH, UK. \\ ${ }^{3}$ Research Centre for Coast and Ocean, Norwegian Institute for Water Research (NIVA), Gaustadalléen 21, \\ $\mathrm{N}-0349$ Oslo, Norway. \\ ${ }^{4}$ Ocean and Earth Science, University of Southampton, National Oceanography Centre, Southampton SO14 3ZH, UK.
}

\begin{abstract}
Summary: This study provides a compilation of all available information on deep-sea echinoderms from the middle and lower slopes of the Mediterranean Sea, with the aim of providing a unified source of information on the taxonomy of this group. Previous records of species are updated with new data obtained from 223 trawl hauls conducted in 11 cruises within the northwestern Mediterranean Sea between $800 \mathrm{~m}$ and $2845 \mathrm{~m}$ depth. Valid names, bathymetric ranges and geographic distributions are given for all species. The new data report, for the first time, the presence of the Atlantic echinoid Gracilechinus elegans (Düben and Koren, 1844) in the Mediterranean Sea. We also report the presence of the endemic holothurians Hedingia mediterranea (Bartolini Baldelli, 1914), dredged only once previously in 1914 in the Tyrrhenian Sea, and Penilpidia ludwigi (von Marenzeller, 1893), known previously only from three samples, two in the Aegean Sea and one in the Balearic Sea. Additionally, the deeper limits of the bathymetric distribution of four species have been expanded: the asteroid Ceramaster grenadensis (Perrier, 1881) to $2845 \mathrm{~m}$; the echinoid Brissopsis lyrifera (Forbes, 1841) to $2250 \mathrm{~m}$; and the holothurians Hedingia mediterranea and Holothuria (Panningothuria) forskali Delle Chiaje, 1823, to $1500 \mathrm{~m}$ and $850 \mathrm{~m}$, respectively.
\end{abstract}

Keywords: deep-sea echinoderms; Mediterranean Sea; Gracilechinus elegans; submarine canyons; taxonomy; bathymetric range.

Primera cita, redescubrimiento y recopilación de los equinodermos de profundidad en el talud continental medio e inferior del Mediterráneo

Resumen: Este estudio presenta una recopilación de toda la información disponible sobre los equinodermos de profundidad en el talud continental medio e inferior del mar Mediterráneo, con el fin de proporcionar una fuente de información unificada sobre la taxonomía de este grupo. Se han actualizado los registros anteriores mediante nuevos datos provenientes de 223 pescas de arrastre de 11 campañas oceanográficas realizadas en el noroeste Mediterráneo entre 800 y $2845 \mathrm{~m}$ de profundidad. Se ha actualizado el nombre de las especies, sus rangos batimétricos y sus distribuciones geográficas. Los nuevos datos presentan, por primera vez, la presencia del equinoideo Atlántico Gracilechinus elegans (Düben and Koren, 1844) en el mar Mediterráneo. También se cita la presencia en el noroeste Mediterráneo de dos especies de holoturias endémicas del Mediterráneo, Hedingia mediterranea (Bartolini Baldelli, 1914), muestreada una única vez en 1914 en el mar Tirreno, y Penilpidia ludwigi (von Marenzeller, 1893), muestreada tres veces, dos en el mar Egeo y una en el mar Balear. Además se expanden los límites de distribución batimétrica para cuatro especies: el asteroideo Ceramaster grenadensis (Perrier, 1881) hasta 2845 $\mathrm{m}$; el equinoideo Brissopsis lyrifera (Forbes, 1841) hasta los $2250 \mathrm{~m}$; y las holoturias Hedingia mediterranea y Holothuria (Panningothuria) forskali Delle Chiaje, 1823, hasta los $1500 \mathrm{~m}$ y $850 \mathrm{~m}$ respectivamente.

Palabras clave: equinodermos de profundidad; mar Mediterráneo; Gracilechinus elegans; cañones submarinos; taxonomía; rango batimétrico.

Citation/Como citar este artículo: Mecho A., Billett D.S.M., Ramírez-Llodra E., Aguzzi J., Tyler P.A., Company J.B. 2014. First records, rediscovery and compilation of deep-sea echinoderms in the middle and lower continental slope of the Mediterranean Sea. Sci. Mar. 78(2): 281-302. doi: http://dx.doi.org/10.3989/scimar.03983.30C

Editor: X. Turon.

Received: November 8, 2013. Accepted: February 21, 2014. Published: May 29, 2014.

Copyright: () 2014 CSIC. This is an open-access article distributed under the Creative Commons Attribution-Non Commercial Lisence (by-nc) Spain 3.0. 


\section{INTRODUCTION}

The deep Mediterranean Sea has a wide variety of geological and ecological settings. Their faunal composition and local biodiversity are largely unknown (Danovaro et al. 2010). The western Mediterranean deep basin is no exception. It has a complex assemblage of markedly different habitats (Sardà et al. 2004), including sedimentary slopes, submarine canyons and seamounts (Company et al. 2012). The specific geomorphological characteristics of these habitats (e.g. the elevation of seamounts, the walls and axes of the submarine canyons and the inclination of the continental slopes) and associated abiotic processes (e.g. variation in oceanographic currents, hard vs. soft substratum and food availability) result in large-scale heterogeneity of the continental margin seafloor (Carpine 1970, Emig 1997, D’Onghia et al. 2003). This high habitat heterogeneity plays a major role in the establishment and maintenance of diverse faunal communities (Levin et al. 2010), which, to date, are still largely unexplored in the deep Mediterranean Sea (Bienhold et al. 2013, Mecho et al. 2014).

The shallow Mediterranean marine fauna inhabiting the shelf and upper slope areas have been studied since ancient times. Consequently, they are relatively well known at many levels (taxonomic, ecological, and biological) (Riedl 1986, Bolam et al. 2002, Danovaro and Pusceddu 2007, Coll et al. 2010). Nevertheless, because of the difficulties in sampling the deep sea, the bathyal and abyssal fauna of the Mediterranean Sea remains poorly studied (Pérès and Picard 1956a, Fredj 1974, Galil and Goren 1995, Danovaro et al. 2010, Tecchio et al. 2011a,b).

The description of the benthic fauna occurring deeper than $800 \mathrm{~m}$ in the Mediterranean started in the $19^{\text {th }}$ century. Cruises carried out by the RN Washington (1881-1882) and SMS Pola (1890-1898) provided the first extensive descriptions of bathyal and abyssal Mediterranean fauna (Marenzeller 1893, Bartolini Baldelli 1914), including many new species of noncrustacean invertebrates. From the late 1920s to the 1960s the number of deep-sea Mediterranean research cruises decreased, resulting in limited new information (Pérès and Picard 1956a,b, Pérès 1958). Since the late 1970s, improvements in sampling methods and equipment have allowed a second period of deep-sea scientific exploration and investigation below $1000 \mathrm{~m}$ depth, conducted by ships such as the Bambu, Mango, and Ruth Ann in Italian waters, the RV Jean Charcot in the Alboran Sea, and the RV Garcia del Cid in the Balearic Sea.

Specimens collected by these expeditions have stimulated a number of publications and new records of species (Carpine 1970, Parenzan 1970, Reyss 1971, Fredj 1974). However, most of this deep-sea literature focuses on the dominant groups such as fishes and crustaceans, the commercial use of Mediterranean marine resources, and the management of these resources (Sardà et al. 1994, 2004, Moranta et al. 1998, Company et al. 2004, Aguzzi et al. 2009, Bahamon et al. 2009). Thus, both fish and crustaceans are well known taxonomically in comparison with other megafaunal groups, such as ascidians, sponges, echinoderms, sipunculans and echiurans (Monniot and Monniot 1975, Alvà 1987a, Uriz and Rosell 1990, Villanueva 1992, Pancucci-Papadopoulou et al. 1999, Quetglas et al. 2000).

In this context, Mediterranean Echinodermata from middle and lower slopes have been poorly studied, particularly in comparison with the Atlantic Ocean, where echinoderms are important in terms of abundance, biomass and ecosystem function (Billett 1991). The large number of investigations conducted in the Atlantic Ocean have resulted in a good taxonomic knowledge of the echinoderms (Mortensen 1903, 1927, 1943, Koehler 1921, 1927, Hérouard 1923, Hyman 1955, Sibuet 1979, Borrero Perez et al. 2003, among others). In contrast, there have only been a few studies on the taxonomy of Mediterranean deep-sea echinoderms (Marenzeller 1893, Bartolini Baldelli 1914, Tortonese 1954, 1965, Sibuet 1974, Alvà 1987b). Most reports provide only species lists; morphological descriptions are of secondary importance (Cherbonnier and Guille 1967, Alvà 1987a, 1991, Koukouras et al. 2007) or totally absent (Tortonese 1958, 1972, 1979, Pérez-Ruzafa and LópezIbor 1988, Rinelli 1998, Coll et al. 2010).

It is in this context of dispersed and relatively scarce information that we have undertaken a study of all bathyal echinoderms, including samples collected in the last five years in the northwestern Mediterranean in the framework of four different projects. New records of species and their bathymetric distributions have been added to provide a thorough review of existing data and an updated account of the taxonomy, geographical and bathymetrical distribution of bathyal echinoderms in the Mediterranean Sea.

\section{MATERIALS AND METHODS}

\section{New echinoderm samples}

Ten oceanographic cruises were conducted between October 2008 and April 2013 to sample the deep seafloor of the western Mediterranean Sea. The sampling areas included the Blanes Canyon and its adjacent open slope, the Palamós Canyon (also named La Fonera) and the Cap de Creus Canyon (Fig. 1). These cruises took place in the framework of three Spanish research projects (PROMETEO, DOSMARES, and PROMARES) sampling at depths between 850 and $2845 \mathrm{~m}$. Additionally, a trans-Mediterranean cruise took place in the context of the European project BIOFUN (EuroDEEP Eurocores, European Science Foundation) in July 2009. This cruise sampled the western, central and eastern Mediterranean basins at 1200, 2000 and 3000 $m$ depth. In addition, a 4000-m depth station was sampled in the central basin. However, because of the low number of echinoderms collected in the central and eastern basins $(n=2)$, only the western Mediterranean samples were used in the present study (Fig. 1).

A total of 223 deployments were completed (Table $1)$, resulting in a total swept area of $10.3 \mathrm{~km}^{2}$. Of these 


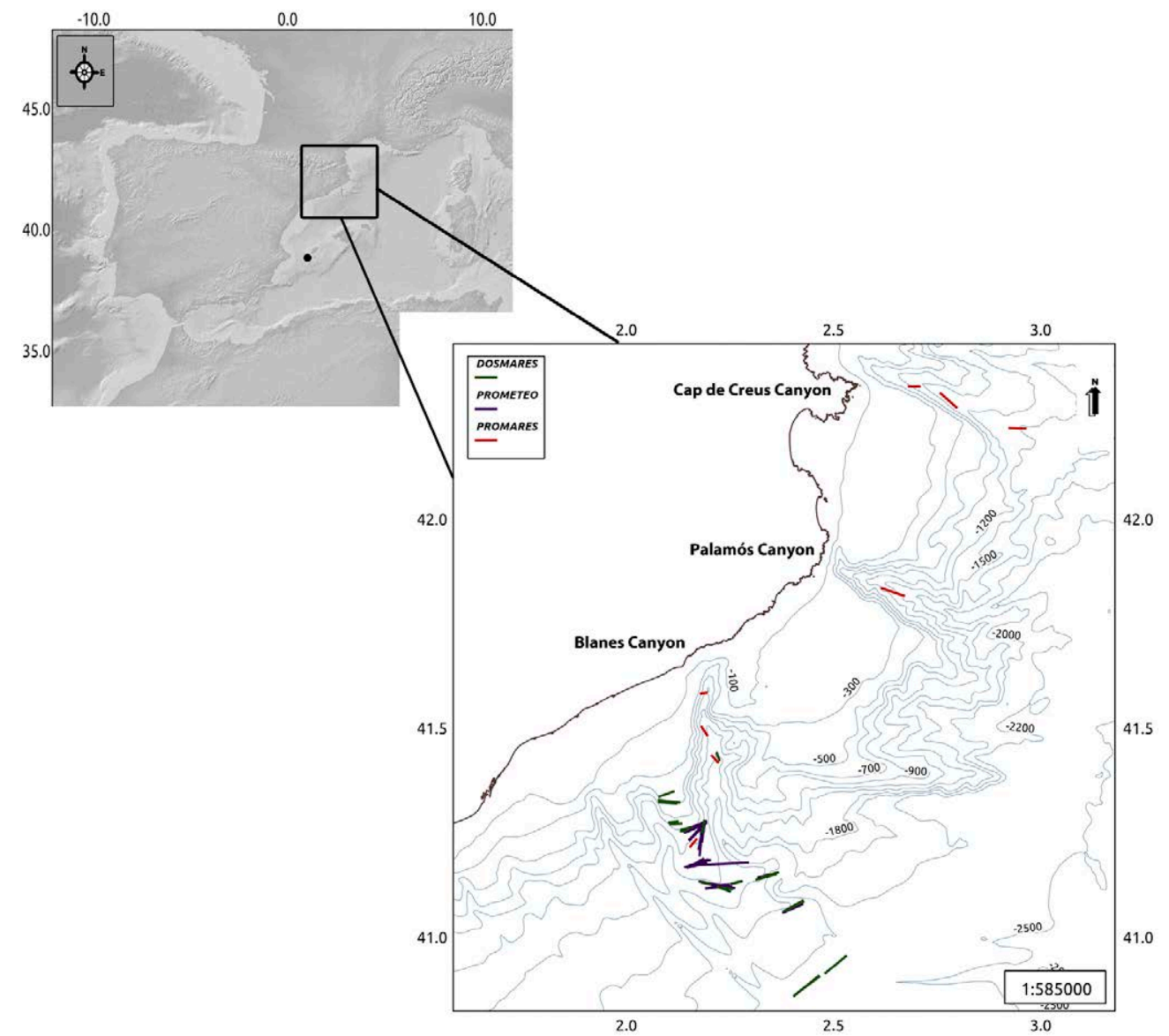

Fig. 1. - Study area. Areas sampled on the cruises PROMETEO, DOSMARES and PROMARES to the Blanes Canyon, Palamós Canyon, Cap de Creus Canyon and the adjacent open slope.

hauls, 119 samples were obtained by a single-warp otter-trawl Maireta system (OTMS, Sardà et al. 1998) with a net length of $25 \mathrm{~m}$ and a cod-end mesh size of $40 \mathrm{~mm}$. A SCANMAR system was used to estimate the width of the net mouth. An average horizontal opening of $12.7 \pm 1.4 \mathrm{~m}$ was calculated. As the SCANMAR system can only operate down to $1200 \mathrm{~m}$ depth, the same value for the net mouth width was used also for deployments deeper than $1200 \mathrm{~m}$. The height of the trawl mouth was estimated to be $1.4 \mathrm{~m}$ (Sardà et al. 1998). In addition, 49 hauls were conducted with an Agassiz dredge made of a square steel frame with a mouth width of $2.5 \mathrm{~m}$ and a mouth height of $1.2 \mathrm{~m}$, and fitted with a 12-mm mesh net. Further, 55 samples were obtained with an epibenthic sledge, which consisted of a rectangular steel frame with three nets attached at different heights $(10-50 \mathrm{~cm}, 55-95 \mathrm{~cm}$ and 100-140 cm above the bottom) with a mesh size of $300 \mu \mathrm{m}$ (only one epibenthic sledge sample contained echinoderms).

Faunal samples were also obtained from 15 bottles in five different sediment traps deployed in the Blanes Canyon axis from November 2008 to February 2009, four of them at $1200 \mathrm{~m}$ and one at $1500 \mathrm{~m}$ depth. All were deployed at $22 \mathrm{~m}$ above the bottom.

Table 1. - Number of benthic trawls and dredges used in the present study by depth and geomorphological area. Canyon area (including La Fonera, Cap de Creus and Blanes canyons). A.C, Agassizz trawl sampled on Canyon area; OTMS.C, otter-trawl Maireta system sampled on Canyon area; ES.C, epibenthic sledge sampled on Canyon area; A.O.S, Agassizz trawl sampled on open slope; OTMS.O.S, otter-trawl Maireta system sampled on open slope; ES.O.S, epibenthic sledge sampled on open slope.

\begin{tabular}{|c|c|c|c|c|c|c|c|}
\hline \multirow[t]{2}{*}{ Depth } & \multicolumn{3}{|c|}{ Canyon } & \multicolumn{3}{|c|}{ Open slope } & \multirow[b]{2}{*}{ Total } \\
\hline & A.C & OTMS.C & ES.C & A.O.S & OTMS.O.S & ES.O.S & \\
\hline 850 & 1 & 1 & 0 & 0 & 0 & 0 & 2 \\
\hline 900 & 4 & 1 & 2 & 7 & 18 & 7 & 39 \\
\hline 1050 & 0 & 0 & 0 & 5 & 10 & 5 & 20 \\
\hline 1200 & 2 & 0 & 1 & 9 & 21 & 10 & 43 \\
\hline 1350 & 0 & 0 & 0 & 3 & 11 & 5 & 19 \\
\hline 1500 & 6 & 8 & 3 & 5 & 18 & 11 & 51 \\
\hline 1750 & 0 & 0 & 1 & 2 & 8 & 3 & 14 \\
\hline 2000 & 0 & 0 & 1 & 2 & 12 & 3 & 18 \\
\hline 2250 & 1 & 2 & 1 & 1 & 4 & 2 & 11 \\
\hline 2850 & 0 & 0 & 0 & 1 & 5 & 0 & 6 \\
\hline Total & 14 & 12 & 9 & 35 & 107 & 46 & 223 \\
\hline
\end{tabular}


Table 2. - Echinoderms sampled in the present study from the deep Mediterranean Sea. * 19 specimens of $P$. ludwigi were collected in sediment trap samples in the Blanes Canyon.

\begin{tabular}{|c|c|c|c|c|}
\hline \multirow[t]{2}{*}{ Species } & \multicolumn{2}{|c|}{ N. sampled } & \multirow[t]{2}{*}{$\mathrm{N}$ total } & \multirow[t]{2}{*}{ Depth of occurrence $(\mathrm{m})$} \\
\hline & Open slope & Canyon & & \\
\hline \multicolumn{5}{|l|}{ ASTEROIDEA } \\
\hline Ceramaster grenadensis (Perrier, 1881) & 146 & 3 & 149 & $850-2845$ \\
\hline Hymenodiscus coronata (G.O. Sars, 1872) & 31 & 16 & 47 & $1500-2250$ \\
\hline \multicolumn{5}{|l|}{ ECHINOIDEA } \\
\hline Gracilechinus elegans (Danielssen and Koren, 1883) & 0 & 7 & 7 & 1500 \\
\hline Brissopsis lyrifera (Forbes, 1841) & 5 & 482 & 487 & $900-2250$ \\
\hline \multicolumn{5}{|l|}{ HOLOTHUROIDEA } \\
\hline Mesothuria (Allantis) intestinalis (Ascanius, 1805) Östergren, 1896 & 52 & 4 & 56 & $900-1750$ \\
\hline Pseudostichopus occultatus von Marenzeller 1893 & 474 & 0 & 474 & $2000-2250$ \\
\hline Holothuria (Panningothuria) forskali Delle Chiaje, 1823 & 0 & 1 & 1 & 850 \\
\hline Molpadia musculus Risso, 1826 & 25 & 0 & 25 & $900-1050$ \\
\hline Hedingia mediterranea (Bartolini Baldelli, 1914) Tortonese, 1965 & 1 & 10 & 11 & $900-1500$ \\
\hline Penilpidia ludwigi (von Marenzeller, 1893) & 200 & $19 *$ & 219 & $900-1500$ \\
\hline Ypsilothuria bitentaculata (Ludwig, 1893) & 27 & 0 & 27 & $900-1350$ \\
\hline Total number of echinoderms collected & 961 & 542 & 1503 & $850-2845$ \\
\hline
\end{tabular}

Finally, video-observations were made during the PROMARES cruise using the remotely operated vehicle (ROV) Liropus 2000. Thirty six video transects were conducted along the axes of the Blanes, Palamós and Cap de Creus canyons between depths of 300 and $1800 \mathrm{~m}$.

A total of 1503 individuals belonging to 11 species were sampled (Table 2). Of these, 196 were asteroids, 494 echinoids and 813 holothurians. The classes Crinoidea and Ophiuroidea were absent from all samples.

\section{Specimen identification}

The echinoderms were sorted, weighed, counted and fixed with $40 \%$ formalin diluted with seawater and neutralized with borax on board ship. After 30 days, the samples were transferred to $70 \%$ alcohol in the laboratory for further examination. Some specimens were fixed in absolute ethanol on board to allow for molecular analyses (not included in this study). All specimens are stored in the Biological Reference Collection of the Institute of Marine Science, Barcelona (Spain).

In the laboratory, all specimens were classified to species level. For microscopic examination of holothurian spicules, small pieces of soft tissue (i.e. skin, tentacles and gonads) were dissolved in bleach solution and mounted on glass slides for identification. The taxonomic results were compared with previous taxonomic studies. The nomenclature was checked against the World Register of Marine Species (WoRMS). The identification of the echinoid Gracilechinus elegans (Düben and Koren, 1844) was based on taxonomic descriptions from the Atlantic Ocean (Mortensen 1903, 1927, 1943, Koehler 1927, Minin 2012). This species has not been cited previously in the Mediterranean Sea. Its geographic distribution was compared with data in the Atlantic Ocean and other echinoid records from the Mediterranean Sea.

\section{Synthesis of taxonomic information on deep-sea Mediterranean echinoderms}

A comprehensive table was created of all the echinoderms present in the Mediterranean Sea and cited

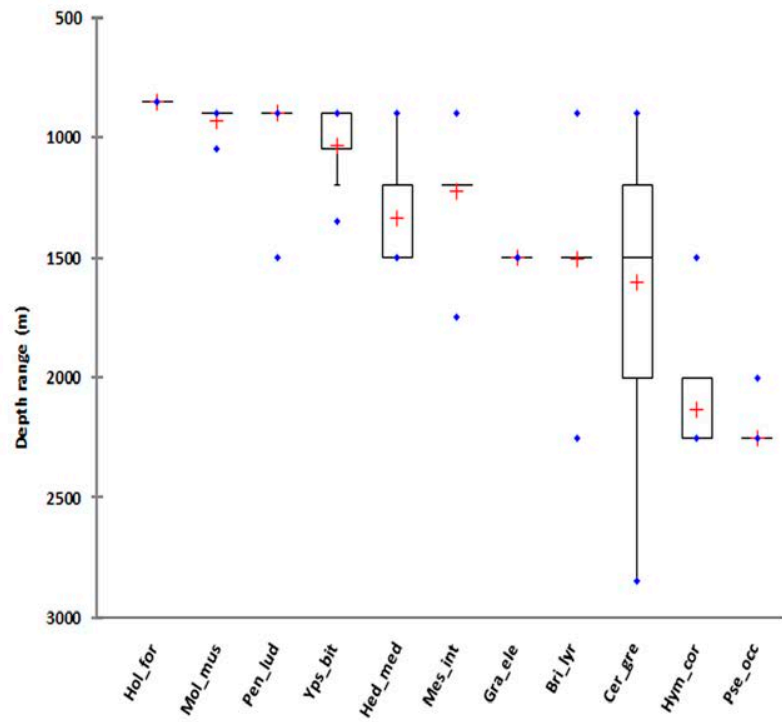

Fig. 2. - Bathymetric distribution and densities of echinoderms sampled in present study. The top and bottom of each box-plot represent $75 \%$ (upper quartile) and $25 \%$ (lower quartile) of all values, respectively. The horizontal line is the median. The ends of the whiskers represent the 10th and 90th percentiles. Cross marks represent means and blue spots maximum and minimum depth of occurrence. Species codes: Hol_for, Holothuria (Panningothuria) forskali; Mol_mus, Molpadia musculus; Pen_lud, Penilpidia ludwigi; Yps_bit, Ypsilothuria bitentaculata; $\mathbf{H e d}$ med, Hedingia mediterranea; Mes int, Mesothuria (Allantis) intestinalis; Gra ele, Gracilechinus elegans; Bri_lyr, Brissopsis lyrifera; Cer_gre, Ceramaster grenadensis; Hym_cor, Hymenodiscus coronata; and Pse_occ, Pseudostichopus occultatus.

in the literature as having a maximum depth of occurrence below $800 \mathrm{~m}$ (see Table 3). This table was constructed based on Tortonese (1965) and Koukouras (2007). New data acquired during the PROMETEO, DOSMARES and PROMARES cruises was added (see above).

\section{RESULTS}

Class ASTERIODEA de Blainville, 1830

Two species of Asteroidea were collected in our study: Ceramaster grenadensis (Perrier, 1881) $(\mathrm{n}=149)$ 

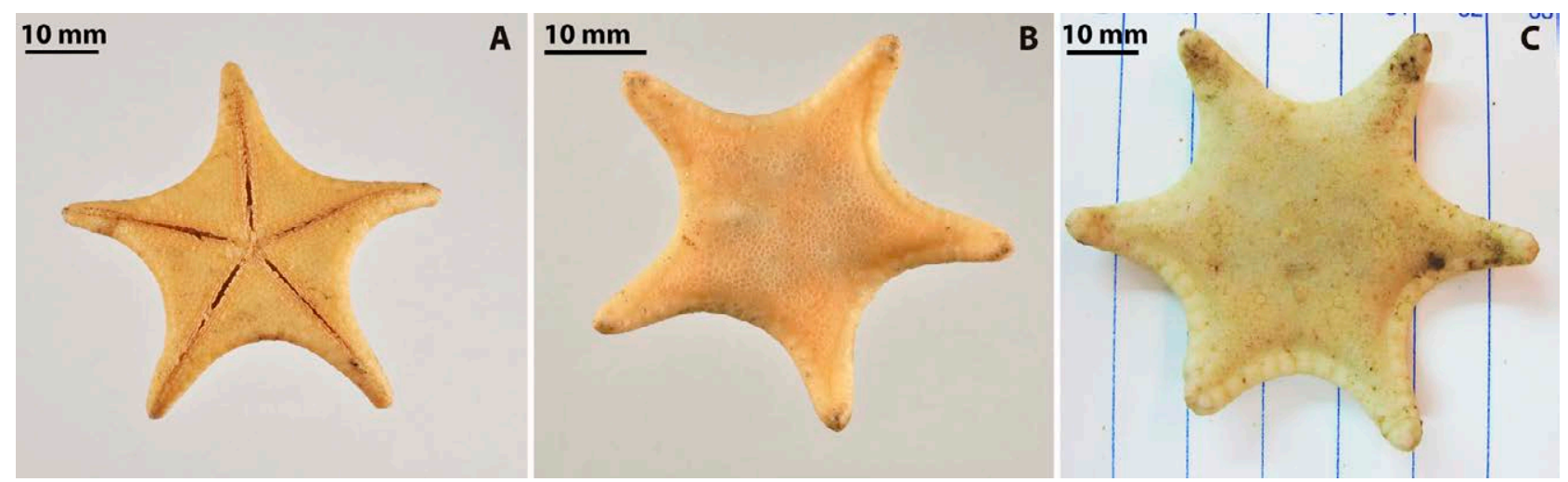

Fig. 3. - Ceramaster grenadensis. A, dorsal view; B, ventral view (Photo: A. Bozzano, ICM-CSIC); C, specimen with six arms.

and Hymenodiscus coronata (G.O. Sars, 1872) ( $\mathrm{n}=47)$. Both are bathyal species. Ceramaster grenadensis sampled in the present study has a wide bathymetric range (850 to $2845 \mathrm{~m}$, Fig. 2). The second species, Hymenodiscus coronata shows a narrower bathymetric range (1500 to $2250 \mathrm{~m}$; Fig. 2).

Order VALVATIDA Perrier, 1884

Family GONIASTERIDAE Forbes, 1841

Genus Ceramaster Verrill, 1899

Ceramaster grenadensis (Perrier, 1881) (Fig. 3)

Pentagonaster deplasi Perrier, 1885: 34. Pentagonaster gosselini Perrier, 1885: 35.

Pentagonaster haesitans Perrier, 1885: 36.

Ceramaster grenadensis Halpern, 1970: 213-218, Figs. 8-9.

Material: 149 specimens collected during the PROMETEO 01-0203-04-05, BIOFUN, PROMARES and DOSMARES 01-02-03-04 cruises. Depth of occurrence: from 850 to $2845 \mathrm{~m}$. Zones: western Mediterranean Sea open slope, Blanes Canyon, Cap de Creus Canyon (Table 2).

Description: Shape pentagonal to stellate, very variable (Fig. 3A, B). Body flattened dorso-ventrally. Oral and aboral surface composed by more or less tabulate hexagonal plates covered by little granules. Marginal plates thick and massive, from 18 to 22; sampling methods could remove them. $\mathrm{R}=6$ to $45 \mathrm{~mm}$. $\mathrm{r}=3$ to $25 \mathrm{~mm} . \mathrm{R} / \mathrm{r}=1.54$ to 2.53 . Colour variable, from cream, pale-yellow to pale pink. Polygonal madreporite, well defined, larger than surrounding plates. Adambulacral plate with 4 to 6 furrow spines, outside these a series of usually four club-shaped spines and outer spines similar to internal ones. Pedicellariae valvate, scarce on aboral side, larger and more numerous on oral side near ambulacral furrow. One of the specimens collected in the present study had six arms (Fig. 3C)

Distribution: Atlantic Ocean and Mediterranean Sea (Clark and Downey 1992).

New depth range: $200-2845 \mathrm{~m}$ (present study). The previous reported maximum depth of distribution for this species was $2500 \mathrm{~m}$ in the Atlantic Ocean (Clark and Downey 1992). The previous Mediterranean Sea bathymetric range was 600-2400 m (Tortonese 1972).
Remarks: Similarities were observed between the genus Litonotaster described by Halpern $(1969,1970)$. However, owing to 1) the absence of the characteristic flat and thin abactinial plates of the genus Litonotaster, and 2) the presence of tabulate abactinial plates covered by granules, the marginal plate disposition, and in agreement with available literature, we consider our specimens to be Ceramaster grenadensis. Litonotaster has not been reported in the Mediterranean Sea. Great intraspecific morphological variations have been signalled for Ceramaster grenadensis in the Mediterranean (Halpern 1970, Tortonese 1972, Sibuet 1974, Alvà 1987a). It is likely that a revision of the genus Ceramaster is needed.

Order BRISINGIDA Fisher, 1928

Family BRISINGIDAE G.O. Sars, 1875

Genus Hymenodiscus Perrier, 1884

Hymenodiscus coronata (G.O. Sars, 1872)

(Fig. 4)

Brisinga coronata Sars, 1873: 102

Brissingella coronata Tortonese, 1965: 194-196, Fig. 93.

Material: 47 specimens collected during cruises PROMETEO 05, BIOFUN and DOSMARES 01-02. Depth of occurrence: from 1500 to $2250 \mathrm{~m}$. Zones: western Mediterranean Sea open slope and Blanes Canyon (Table 2).

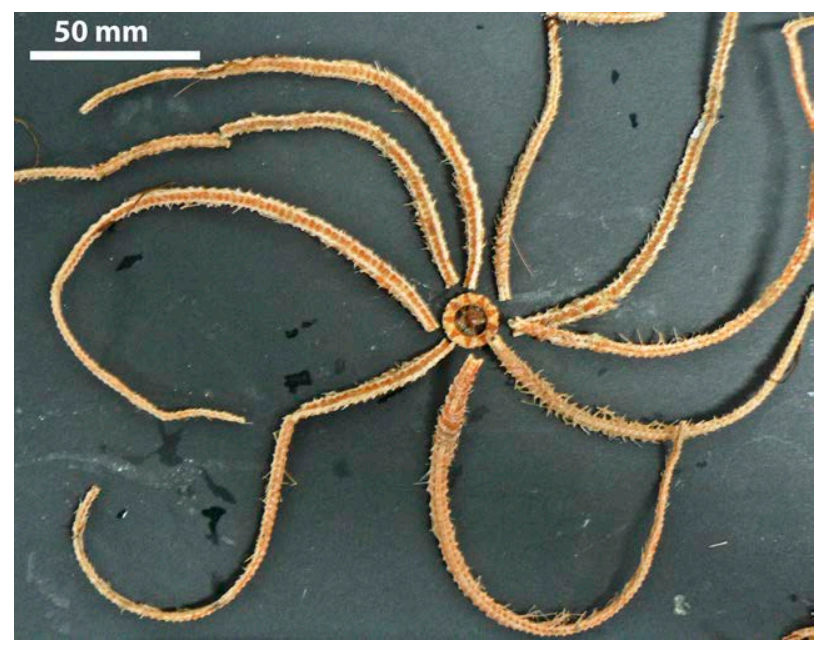

Fig. 4. - Hymenodiscus coronata. 
Description: Diameter of disc $11 \mathrm{~mm}$; from 9 to 13 long and slender arms. Colour orange to reddish. Very difficult to collect intact, usually the disc and the arms are broken and separate (Fig. 4). Madreporite large, channelled. Gonadal region slightly to highly inflated. Abactinal arm plates rod-like. Two to four tiny, acicular furrow spines and one to two moderately long subambulacral ones.

Distribution: North Atlantic and Mediterranean Sea (Alvà 1987a).

Depth range: 100-2904 m (Bartolini Baldelli 1914).

Remarks: Description taken from (Clark and Downey 1992).

\section{Class ECHINOIDEA Leske, 1778}

Only two sea urchin species were sampled: the regular echinoid Gracilechinus elegans (Düben and Koren, 1844) $(\mathrm{n}=7)$ and the irregular echinoid Brissopsis lyrifera (Forbes, 1841) $(\mathrm{n}=487)$. Gracilechinus elegans, known in the Atlantic, has been reported for the first time in the Mediterranean Sea in the present study. It was sampled in the Blanes Canyon at 1500 $m$ depth (Fig. 2). Other specimens were observed and collected with the ROV during the PROMARES cruise (Mecho, pers. obs.) in the lower Palamós Canyon and Blanes Canyon areas $(1500 \mathrm{~m})$. Brissopsis lyrifera was found over a wide bathymetric range in the present study (from 900 to $2250 \mathrm{~m}$; Fig. 2). It was abundant in some canyons between 900 and $1500 \mathrm{~m}$ (Table 2). In contrast, only five small specimens of $B$. lyrifera were collected on the open slope at depths between 1750 and $2250 \mathrm{~m}$ (Table 2).

Order CAMARODONTA Jackson, 1912 Family ECHINIDAE Gray, 1825

Genus Gracilechinus Fell and Pawson, in Moore, 1966

Gracilechinus elegans (Düben and Koren, 1844) (Fig. 5)

Echinus elegans Düben and Koren, 1844: 272. Koehler, 1927: 5153, pl. XII, Fig. 12 a-g; pl. XVII, Fig. 5

Material: 7 specimens from cruises PROMETEO 04, PROMARES and DOSMARES 04. Depth of occurrence: $1500 \mathrm{~m}$. Zones: Blanes Canyon and Palamós Canyon (Table 2).

Description: Diameter test 38.5 to $48.3 \mathrm{~mm} ; \mathrm{h}=25.6$ to $34.7 \mathrm{~mm}$. Test low, from conical and flattened above to slightly flattened on both sides, usually the height of the test is more than half the diameter (Fig. 5A). Colour whitish pink to pink, sometimes a few green (Fig. $5 \mathrm{~B}, \mathrm{C})$. Long primary spines usually flat at the end. One primary tubercle present on each plate, forming a very regular series from oral to aboral side; usually secondary ones form a short longitudinal series from the middle to the oral side. A small tubercle is present between the pores and the primary tubercle, but not between the pores and the end of the plate. Some miliary tubercles are present, giving a rough appearance to the test. Three pairs of pores very clear and disposed in a sharp angle. The boundary between the areas was more straight than sinuous. Periproct (Fig. 5D) covered by large irregular plates, one of them with a spine. The plates surrounding the anus are irregularly club-shaped and smaller than the other plates. Ocular plates not in contact with the periproct. No spines on the buccal plates, where pedicellariae were present and abundant. Tridentate pedicellariae have the valves flat, narrow and mesh-worked, with the edge sinuate (500 to 650 um long). In some cases small individuals had flatter valves than larger individuals (Fig. 5E). These valves have a narrow area near the base (Fig. 5F). Globiferous pedicellariae $(500$ to $550 \mu \mathrm{m})$ usually have 1 or 2 lateral teeth on either side of the blade and a more or less round to rectangular shape (Fig. 5G-I). Ophicephalus pedicellariae, broad, sinuate and with small teeth in the edge, and an intricate mesh-work.

Distribution: North Atlantic (OBIS). First record in the Mediterranean Sea.

Depth range: $50-1710 \mathrm{~m}$. (Mortensen 1943, Minin 2012). Only reported at $1500 \mathrm{~m}$ depth in the Mediterranean Sea (present study).

Remarks: Mortensen (1903) reported this species from the Mediterranean, but he later discarded this identification (Mortensen 1943). Alvà (1987b) described another species, Gracilechinus alexandri, in the Mediterranean Sea. Both $G$. elegans and $G$. alexandri have many similar characteristics, making their true identification difficult (Mortensen 1903, Ramírez-Llodra and Tyler 2006, Minin 2012). Furthermore, juvenile $G$. alexandri have characteristics that might be confused with $G$. elegans. It is possible that the specimen of $G$. alexandri reported by Alvà (1987b) was a juvenile and was a misidentification of $G$. elegans. The specimen is no longer available for comparison. In our specimens, the presence of one or two teeth on the globiferous pedicellariae, their narrow base and their mesh-work are similar to those described in the literature (Mortensen 1903, Minin 2012). The tubercular pattern, the periproct, the shape of the ocular and genital plates and their disposition allowed us to classify these specimens as G. elegans. Mortensen (in 1903, p. 144, pl. XX, Fig. 9) found a small form for $G$. elegans with tridentate pedicellariae that had more flattened and truncate blades without mesh-work. This characteristic and the overlapping range in the number of teeth in the globiferous pedicellariae ( 1 to 4 in G. elegans and 2 to 5 in $G$. alexandri) could lead to a misidentification if only one individual was available, as appears to be the case in Alvà (1987b).

Order SPATANGOIDA Agassiz, 1840a Family BRISSIDAE Gray, 1855

Genus Brissopsis Agassiz, 1847

Brissopsis lyrifera (Forbes, 1841)

(Fig. 6) 

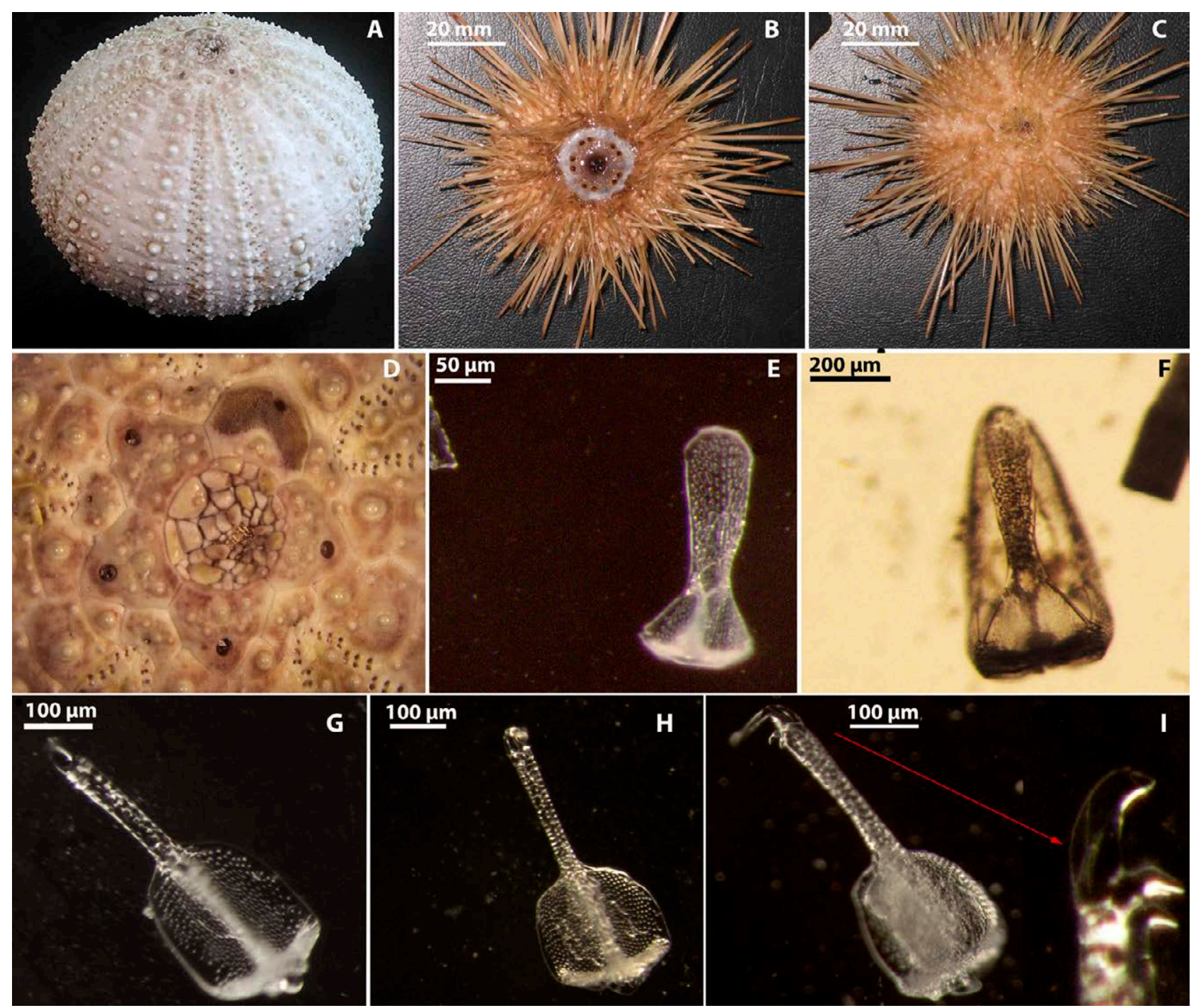

Fig. 5. - Gracilechinus elegans. A, test; B, oral view; C, aboral view; D, periproct structure; E, F, tridentate pedicellariae; G, H, globiferous pedicellariae; I, globiferous pedicellariae, detail of teeth.

Brissus lyrifeer Forbes, 1841: 187

Brissopsis lyrifera Tortonese 1965: 372-374

Material: 487 specimens from cruises PROMETEO 02-04-05, PROMARES and DOSMARES 01-03. Depth of occurrence: 900 to 2250 m. Zones: western Mediterranean Sea open slope, Blanes Canyon, Cap de Creus Canyon and Palamós Canyon (Table 2).

Description: Body oval, arched, sloping anteriorly. Colour from yellow to red-brown with a narrow band of ciliated dark spines which rings all five ambulacra petals on the upper surface (Fig. 6A, B). Anterior ambulacral zone slightly depressed. Periproct terminal, near aboral zone. Posterior petals shorter than the anterior ones, diverging and well separated. Globiferous pedicellariae short, ending in two long teeth. Tridentate pedicellariae of various forms, with three more or less leaf-shaped blades. Rostrate pedicellariae blade slender.

Distribution: Atlantic and Mediterranean Sea (OBIS).
$10 \mathrm{~mm}$

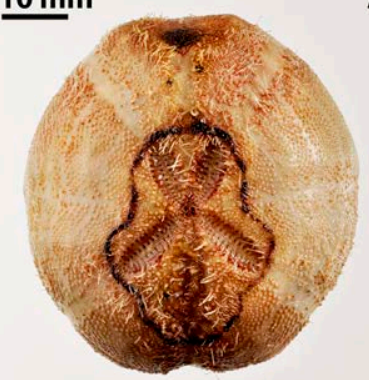

A $10 \mathrm{~mm}$

B

Fig. 6. - Brissopsis lyrifera A, oral view; B, ventral view (Photo from A. Bozzano).

New depth range: $200-2845 \mathrm{~m}$ (present study). The previous reported maximum depth of distribution for this species was $1650 \mathrm{~m}$ in the Atlantic Ocean (OBIS). Previous Mediterranean maximum depth was $1500 \mathrm{~m}$ (Tortonese 1965).

Remarks: Differences from Brissopsis atlantica mediterranea (Mortensen 1913) are evident in the posterior 
petals: diverging and well separated in B. lyrifera and confluent on the base, as opposed to nearly parallel in $B$. atlantica mediterranea (Lacour and Néraudeau 2000).

\section{Class HOLOTHUROIDEA de Blainville, 1834}

The Holothuroidea was the most abundant echinoderm class sampled in this study, with a total of 813 specimens and 7 species (Table 2). Three species belonging to the order Aspidochirotida were collected: Mesothuria (Allantis) intestinalis, (Ascanius, 1805) Östergren, 1896 ( $\mathrm{n}=56)$, Pseudostichopus occultatus, Marenzeller $1893(\mathrm{n}=474)$ and Holothuria (Panningothuria) forskali, Delle Chiaje, $1823(\mathrm{n}=1)$.

In the present study, Mesothuria intestinalis had a bathymetric range between 900 and $1750 \mathrm{~m}$ depth (Fig. 2). In contrast Pseudostichopus occultatus had a very narrow depth range (2000 to $2250 \mathrm{~m}$; Fig. 2). This species was sampled only in open slope areas. Although one individual was collected at $2250 \mathrm{~m}$ depth in the Blanes Canyon, we consider this as a residual sample, based on the high number of specimens collected in the previous catch, the bad condition of the specimen and the absence of this species in other trawls conducted at this depth in the canyon. This species was sampled in great numbers at $2250 \mathrm{~m}$ (maximum of 145 individuals) (Table 2). Only one individual of $H$. forskali was sampled (850 $\mathrm{m}$ in the Blanes Canyon).

The order Molpadiida was represented by two species: Molpadia musculus, Risso, $1826(\mathrm{n}=25)$ and Hedingia mediterranea (Bartolini Baldelli, 1914) Tortonese, 1965 ( $\mathrm{n}=11$ ). Molpadia musculus had a bathymetric range between 900 and $1050 \mathrm{~m}$ depth (Fig. 2) and was sampled only on the open slope. Hedingia mediterranea had a bathymetric range between 900 and $1500 \mathrm{~m}$ (Fig. 2 ) and was sampled mainly in canyon areas.

The order Elasipodida was represented by one species Penilpidia ludwigi (von Marenzeller, 1893) $(n=219)$. The bathymetric distribution of this species ranged from 900 to $1500 \mathrm{~m}$. Most of the individuals $(n=200$; Table 2) were sampled by the epibenthic sledge at a single open slope site in the western Mediterranean Sea at $900 \mathrm{~m}$ depth. A few individuals $(n=19)$ were reported from sediment trap samples located in the Blanes Canyon at 1200 and $1500 \mathrm{~m}$ depth (Fig. 2).

The order Dactylochirotida was represented by a single species: Ypsilothuria bitentaculata (Ludwig, $1893)(n=27)$. This species was distributed in the present study between 900 and $1350 \mathrm{~m}$ depth (Fig. 2) and was sampled only in an open slope area (Table 2).

Order ASPIDOCHIROTIDA

Family Synallactidae Ludwig, 1894

Genus Mesothuria Ludwig, 1894

Subgenus Allantis Heding, 1942

Mesothuria (Allantis) intestinalis (Ascanius, 1805)

Östergren, 1896

(Fig. 7)

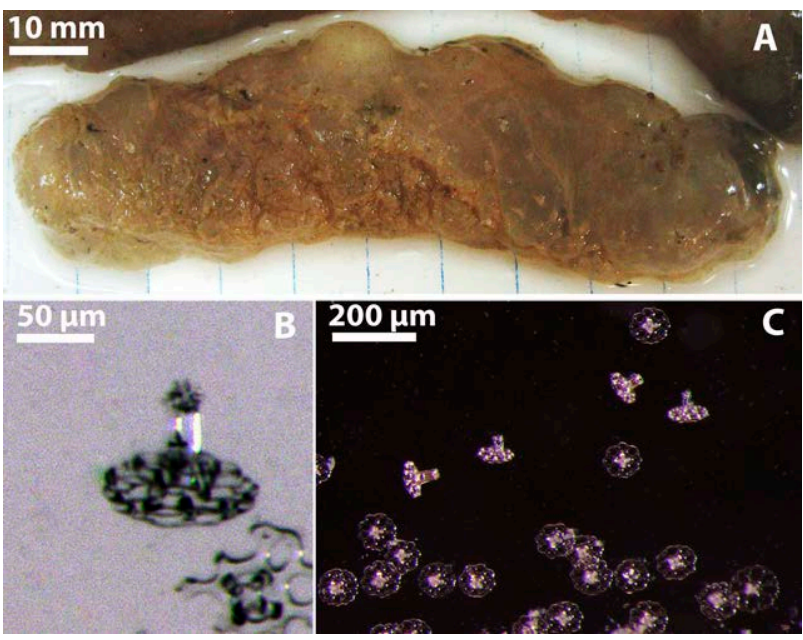

Fig. 7. - Mesothuria (Allantis) intestinalis characteristic. A, general view; B, ossicle crown with several thorns; C, ossicle plates with four rods and central spire.

Material: 56 specimens were collected during cruises PROMETEO 02-03-04-05, BIOFUN and PROMARES. Depth of occurrence: 900 to $1750 \mathrm{~m}$. Zones: western Mediterranean Sea open slope, Blanes Canyon and Cap de Creus Canyon (Table 2).

Description: Large species, up to $30 \mathrm{~cm}$ long (Koehler 1927). Body nearly cylindrical with both ends flattened (Fig. 7A). Mouth subventral surrounded by 20 peltate tentacles. Scattered small tube feet all over the body, more abundant near the anterior and posterior ends. Dermis usually covered by shells, skin very fragile and thin in fresh specimens. On preservation, the dermis becomes thicker and more wrinkled. Characteristic ossicles are round tables $( \pm 100 \mu \mathrm{m})$, more or less regular with small peripheral holes around a central hole, and with central spire built by four rods, ending in a crown of several thorns (Perrier 1898) (Fig. 7B, C). Hermaphroditic species (Hyman 1955), gonads constituted by one branched tuft attached to left side of the dorsal mesentery, with some tubules male and some female, not found ripe at the same time (Mortensen 1927). Two respiratory trees, gelatinous and transparent. The species produces a substance which gels in formaldehyde and alcohol when preserved. Specimens usually eviscerate during capture.

Distribution: Mediterranean Sea, North Atlantic and West Indian seas (Gebruk et al. 2012).

Depth range: 18-2000 m (Gebruk et al. 2012). Mediterranean depth range 20 to $1927 \mathrm{~m}$ (Cartes et al. 2009).

Remarks: The presence of a second Mesothuria species of the genus in the Mediterranean Sea, Mesothuria verrilli (Théel, 1886), was discarded by Gebruk et al. (2012).

Genus Pseudostichopus Ludwig, 1894 Pseudostichopus occultatus Marenzeller 1893 (Fig. 8)

Pseudostichopus occultatus Marenzeller, 1893a: 15-17, pl. 4, Fig. 9. O’Loughlin, 2005: 173-174. 


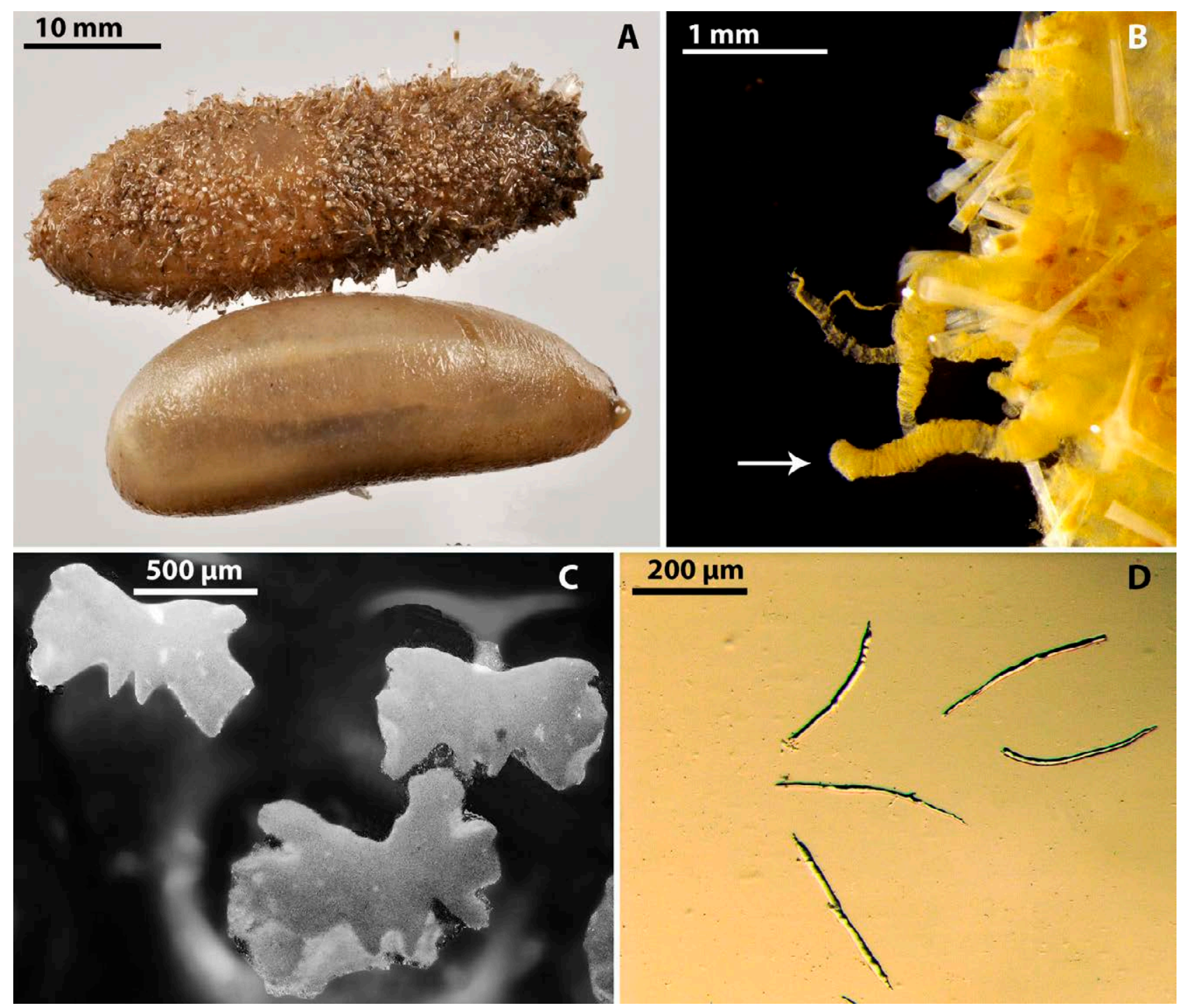

Fig. 8. - Pseudostichopus occultatus characteristics. A, general view, with and without pteropod cover (Photo from A. Bozzano); B, tube feet detail and encrusted pteropods; $\mathrm{C}$, detached pieces of the calcareous ring; D, irregular spiny ossicles from respiratory trees and tentacles.

Material: 474 specimens collected from cruises DOSMARES 0102-04. Depth of occurrence: 2000 and $2250 \mathrm{~m}$. Zone: western Mediterranean Sea open slope (Table 2).

Description: Specimens smaller than $40 \mathrm{~mm}$ long; usually with pteropods and sand encrusted in the skin giving an external vitreous structure, colour dusty brown (Fig. 8A). Body dorsally convex, flat ventrally. The specimens sampled in this study do not have the pygal furrow which is generally characteristic of the group; some authors also note the absence of a pygal furrow in some specimens. Mouth subventral surrounded by 16-20 orange peltate tentacles, anus terminal. When the encrusted material is discarded the dermis is thin. The dorsolateral tube feet are sometimes difficult to see (Fig. 8B). Muscular bands cylindrical and subdivided, visible by transparency. Calcareous ring solid, radial plates with two central and lateral projections providing a ribbon-like shape to each plate (Fig. 8C). Two respiratory trees long and slim clustering along a central strap. Usually dredged in great numbers. Ossicles present in tentacles, tube feet, respiratory trees and near anus; absent in skin and gonads. Spiny rods (150 to $350 \mu \mathrm{m})$ (Fig. 8D) and scarce irregular, meshlike perforate plates. Gonads in one tuft, with long unbranched tubules arising separately along gonoduct; one dissected specimen had little tufts full of eggs free in the coelom.

Distribution: Mediterranean Sea, North Atlantic (O’Loughlin and Ahearn 2005)

Depth range: $360-4400 \mathrm{~m}$ (Koehler 1927). Mediterranean depth range 415 to $3624 \mathrm{~m}$ (Bartolini Baldelli 1914).

Remarks: O'Loughlin (2002) reconsidered the genus Pseudostichopus and classified $P$. occultatus as Meseres occultatus. Later, (O'Loughlin and Ahearn 2005) returned this species to the genus Pseudostichopus. The colour of tentacles and internal structures shows great variability between individuals and is not suitable as a diagnostic character. 


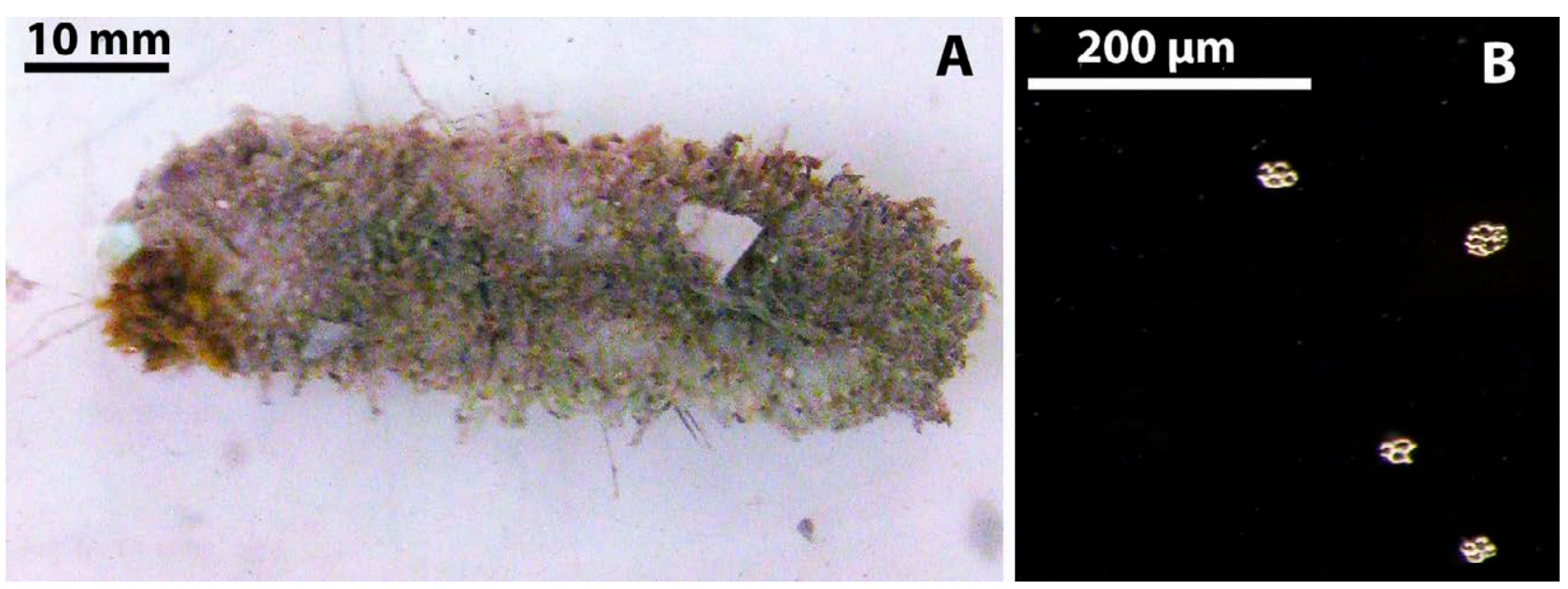

Fig. 9. - Holothuria (Panningothuria) forskali characteristics. A, general view; B, ossicles.

Family HOLOTHURIIDAE Ludwig, 1894

Genus Holothuria Linnaeus, 1767

Subgenus Panningothuria Rowe, 1969

Holothuria (Panningothuria) forskali

Delle Chiaje, 1823

(Fig. 9)

Holothuria forskahli Delle Chiaje, 1824: 77-116, pl. 6-8. Tortonese, 1965: 64, Fig. 23

Material: 1 specimen from cruise PROMETEO 05. Depth of occurrence: 850 m. Zone: Blanes Canyon (Table 2).

Description: $60 \mathrm{~mm}$ long. Cylindrical body flattened ventrally (Fig. 9A). Numerous tube feet in three or four rows. Conical papillae on its dorsal surface. Subventral mouth with about 20 stumpy, branched tentacles. Calcareous deposits scarce, as small discs in skin (Fig. 9B) and branched and curved rods in tube feet and tentacles. Colour, usually black with white spots, sometimes brown with a yellow ventral side. Cuverian tubules are present.

Distribution: Mediterranean Sea and northeast Atlantic Ocean (Pérez Ruzafa et al. 1987).

New depth range: $20-850 \mathrm{~m}$ depth (present study). The previous maximum depth reported for this species in the Atlantic Ocean was 348 m (Pérez Ruzafa et al. 1987). The previous Mediterranean Sea maximum depth was 193 m (Pérez Ruzafa et al. 1987).

Remarks: The one small specimen collected had a pale grey-pinkish colour. Some authors (Koehler 1921, 1927, Tortonese 1965) described deeper specimens of $H$. forskali as pale in colour and smaller in body length compared with shallower individuals. O'Loughlin and Paulay (2007) describe a related species to H. forskali, living at greater depths $(800 \mathrm{~m})$ in Australian waters.

Order MOLPADIIDA

Family MOLPADIIDAE Müller, 1850

Genus Molpadia (Cuvier, 1817) Risso, 1826

Molpadia musculus Risso, 1826

(Fig. 10)
Molpadia musculus Risso, 1826: 293. Pawson, 2001: 317-318, Fig. $2 \mathrm{~A}-\mathrm{B}$.

Material: 25 specimens collected during cruises PROMETEO 0102-03-04-05, PROMARES and DOSMARES 04. Depth of occurrence: 900 and $1050 \mathrm{~m}$. Zones: only present on western Mediterranean Sea open slope (Table 2).

Description: Up to $50 \mathrm{~mm}$ long. Sausage-shaped, with a small tail (Fig. 10A). Terminal, mouth surrounded by 15 pink digitate tentacles with two small prolongations (Fig. 10B). Skin rough and thick, coloured from grey to dark purple due to phosphatic deposits (Fig. 10A, B). Ossicle tables have few perforations and a small solid spine (500 to $700 \mu \mathrm{m}$ ). Rosette and racquet-shape plates and anchors present (Fig. 10C). Fusiform rods $( \pm 1000 \mu \mathrm{m})$ always present in tail, usually also on body wall (Fig. 10D). Calcareous ring with posterior bifurcate projections on radial plates. Two long and slender respiratory trees. Ossicles and body shape could vary, but fusiform rods of the tail are diagnostic. Colour varies with the age and growth of the animal. In the early stages they are grey-white and, when grown to the adult size, the colour turns darker from the accumulation of phosphatic deposits.

Distribution: Cosmopolitan (Pawson et al. 2001).

Depth range: 35-5205 m (Pawson et al. 2001). Mediterranean Sea depth range 50 to 2500 m (Parenzan 1970).

Remarks: In the Mediterranean Sea, the maximum depth of distribution for this species was $1050 \mathrm{~m}$ (Tortonese 1965, Sibuet 1974, Cartes et al. 2009, RamírezLlodra et al. 2010, present study). However, Parezan (1970, pp. 10 and 33) sampled ten M. musculus between 2300 and 2500 m, with the RV Ruth Ann in 1969 while dredging the Ionian Sea (central Mediterranean Sea).

Family CAUDINIDAE Heding, 1931

Genus Hedingia Deichmann, 1938

Hedingia mediterranea (Bartolini Baldelli, 1914) Tortonese, 1965

(Fig. 11) 


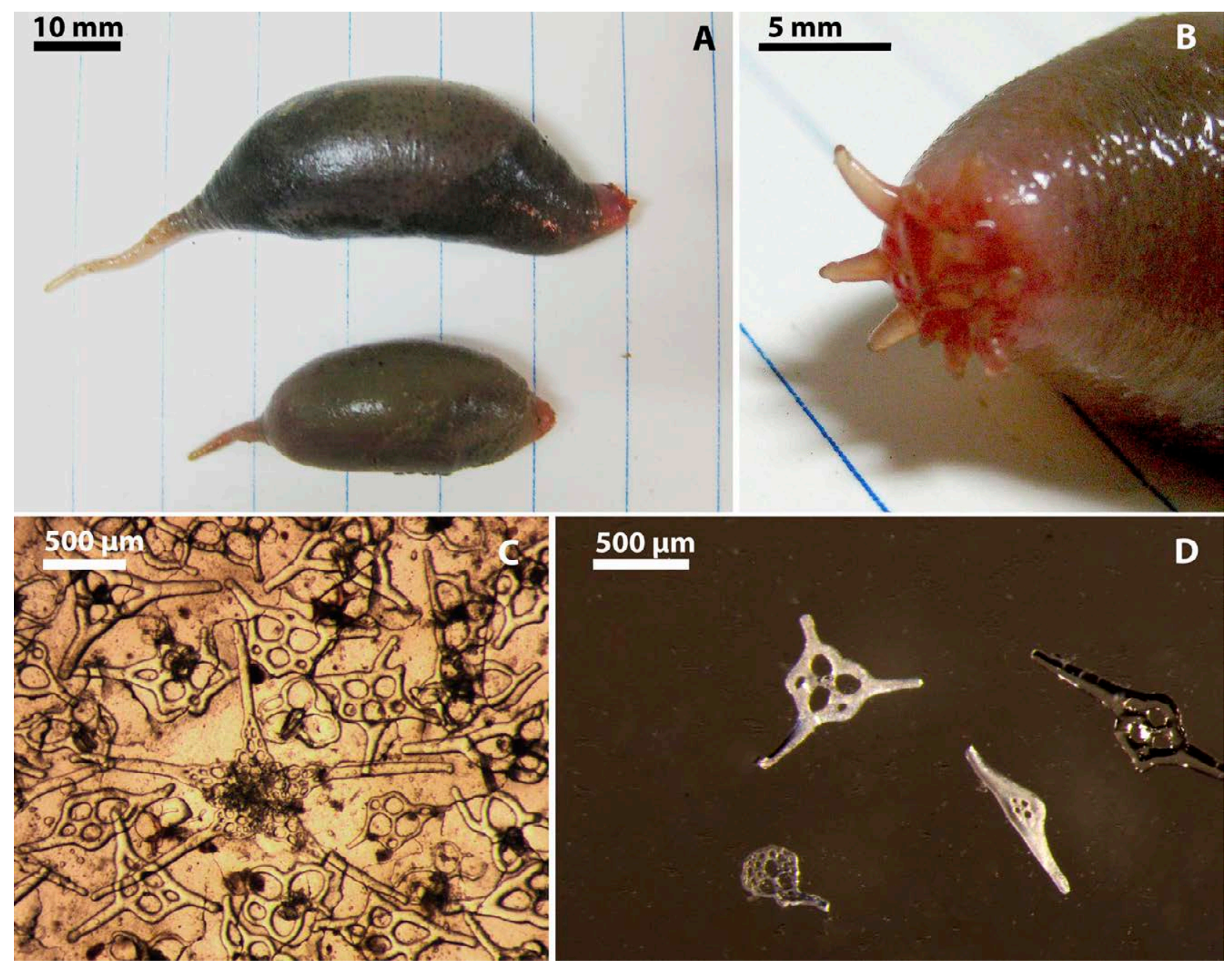

Fig. 10. - Molpadia musculus characteristics. A, general view; B, detail of the tentacles; C, rosettes and racquet-shaped ossicles with phosphatic deposits; D, fusiform rod ossicles from tail.

Trochostoma mediterraneum Bartolini Baldelli, 1914: 105-107, pl. 6 Figs. 9-10.

Hedingia mediterranea Tortonese 1965: 100-101, Fig. 43.

Material: 11 specimens collected from cruises PROMETEO 02-05 and PROMARES. Depth of occurrence: 900 to $1500 \mathrm{~m}$. Zones: western Mediterranean Sea open slope and Blanes Canyon (Table 2).

Description: Fresh specimens pale violet or white, acquiring a yellowish white colouring when conserved (Fig. 11A, B). Body divided into two regions, an elongated body and a long caudal appendage (more than half the length of the body). Body oval, without podia. Rough skin due to calcareous plates. Anterior region wrinkled and cylindrical, with a terminal mouth. Skin without phosphatic deposits. Fifteen tentacles without digitations. Anus situated at the end of the caudal appendage. Five subdivided muscular bands visible by transparency. Ossicles very similar to $H$. albicans; tables (from 150 to nearly $250 \mu \mathrm{m}$ ) present all over the skin with very irregular holes and a central spine with three spiny columns (Fig. 11C -E). Smooth plates on anal papillae (Fig. 11F, G). Two respiratory trees (right and left), low-ramified and attached along the mesentery. Gonads long and unbranched tubules extending to the posterior end of the body, disposed in two tuffs attached to the mesentery on the upper part and free for the rest of their length in the coelom (Fig. 11H). Calcareous ring with five radial pieces, each with two posterior bifurcated projections and five interradial pieces (Fig. 11I, J). Tentacular ampullae long and digitate.

Distribution: Endemic from Mediterranean Sea, reported once on Tyrrhenian Sea. First citation in the western Mediterranean Sea.

Depth range: $800-1500 \mathrm{~m}$ (present study). The previous Mediterranean Sea depth range was 800 to 1000 m (Bartolini Baldelli 1914).

Remarks: Only one specimen has been reported previously in the Mediterranean Sea, dredged by RN Washington (1881-1882) in the Tyrrhenian Sea at 800$1000 \mathrm{~m}$ depth and described as Trochostoma mediterraneum by Bartolini Baldelli (1914). Later, Koehler (1927) classified the specimen as Trochostoma articum. Tortonese (1965) classified it definitively as Hedingia mediterranea. Pawson (2001) considered the specimen to be Hedingia albicans (Théel, 1886) Deichmann, 1938, and cited it in the Mediterranean. Molecular data are required for Hedingia species in order to resolve their taxonomic status. 

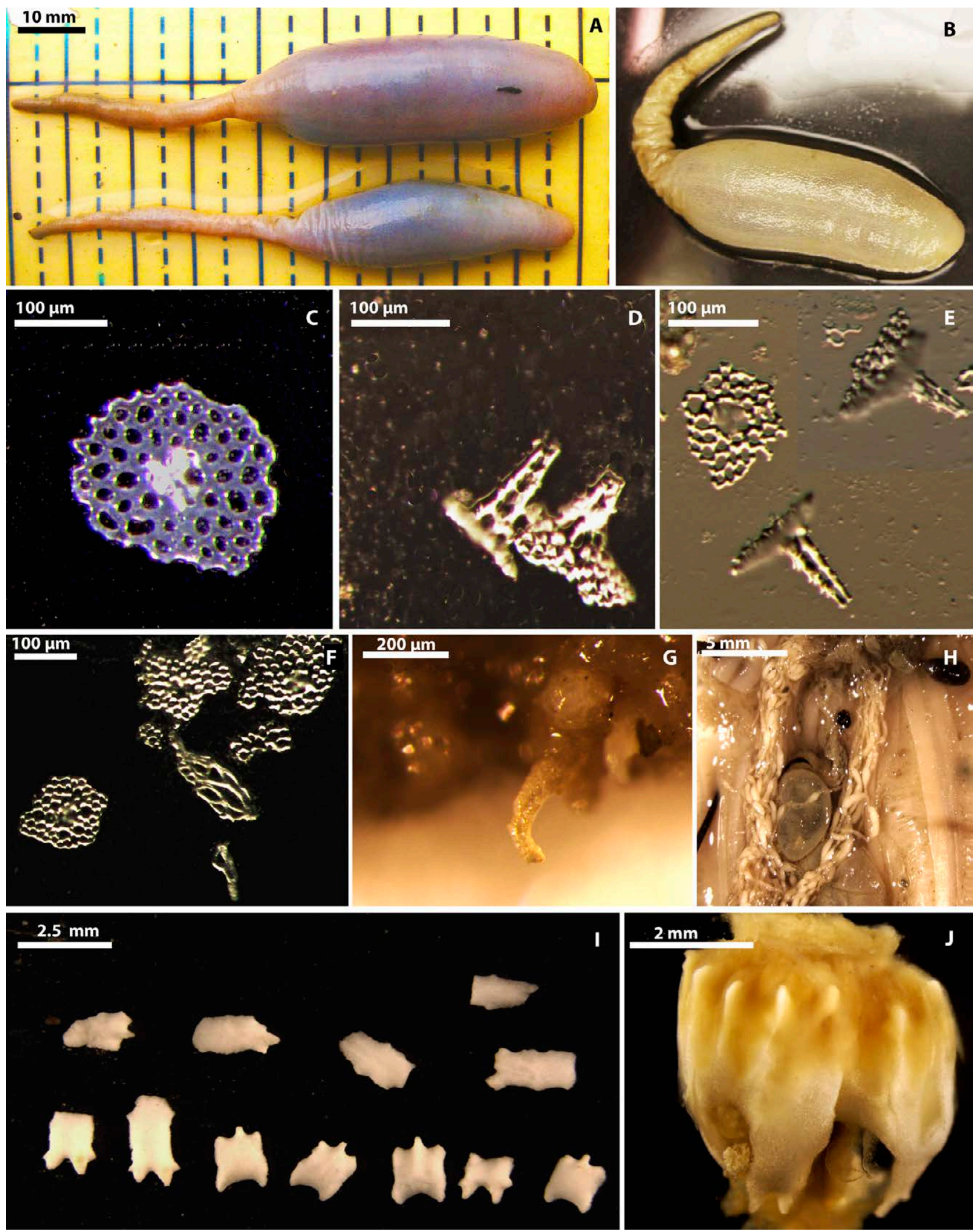

Fig. 11. - Hedingia mediterranea characteristics. A, B, external colour diversity; C, D, skin ossicles; E, detail of ossicles central spine; F, anal calcareous plates; G, anal papillae; H, gonadal tuffs and Polian vesicle; I, J, calcareous ring and detached pieces of calcareous ring.

Order ELASIPODIDA Théel, 1882

Family ELPIDIIDAE Théel, 1879

Genus Penilpidia Gebruk, 1988

Penilpidia ludwigi (von Marenzeller, 1893)
(Fig. 12A-G)

Kolga ludwigi Marenzeller, 1893: 20-23, pl. III Fig. 7, pl. IV Fig. 8. Penilpidia ludwigi Gebruk, 2013: 1030-1032, Fig. 1. 


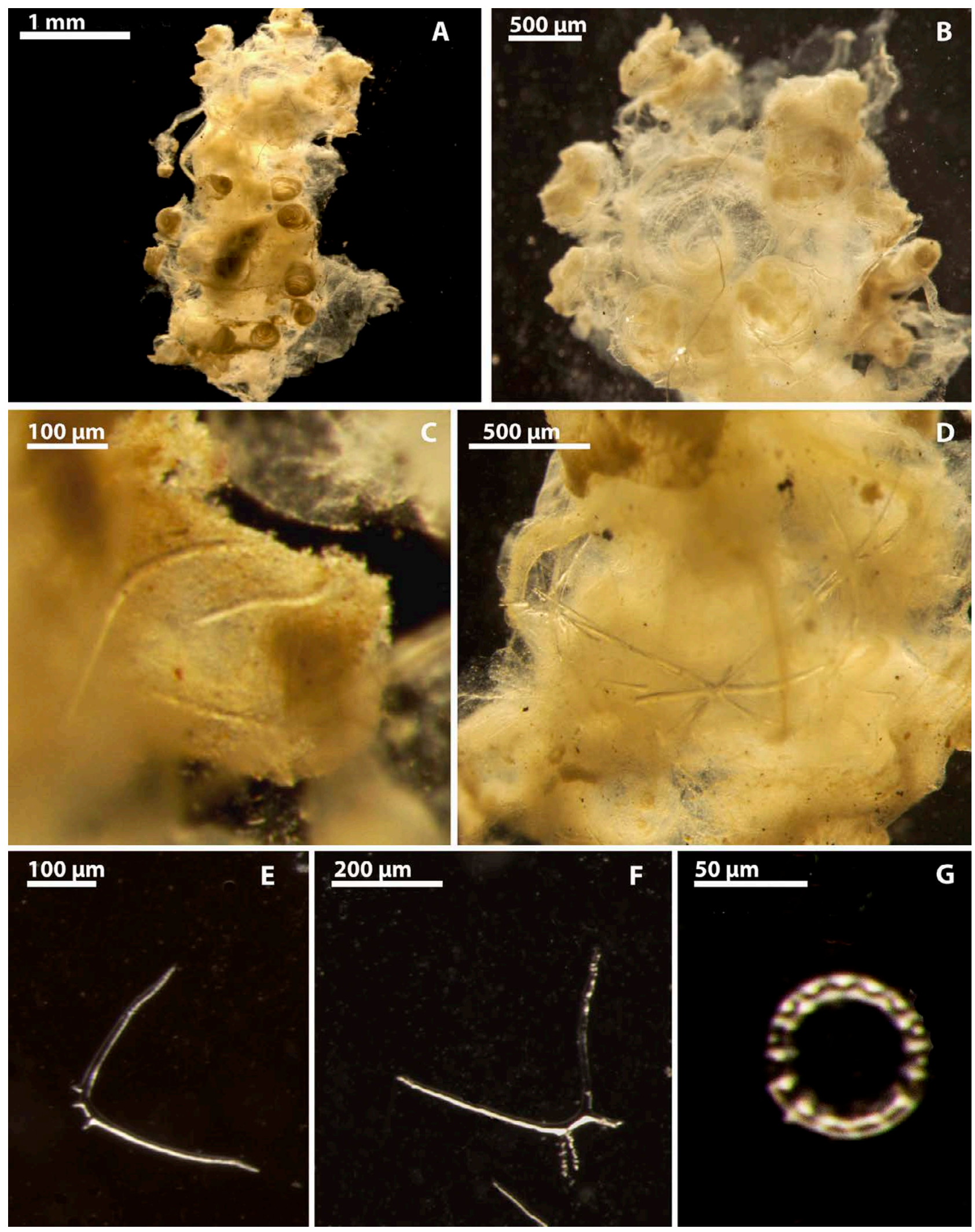

Fig. 12. - Penilpidia ludwigi characteristic. A, general view; B, oral region detail; C, tentacle ossicles; D, interlinked pieces of the calcareous ring; E, F, pieces of the calcareous ring $\mathrm{G}$, wheel from skin.

Material: 219 specimens from cruise PROMETEO 01 and sediment traps of PROMETEO project. Depth of occurrence: from 900 to $1500 \mathrm{~m}$. Zone: western Mediterranean Sea open slope and Blanes Canyon (Table 2).
Description: Small species of 5-20 $\mathrm{mm}$ in length. Fragile animals with skin usually broken. Digestive tract visible by transparency (Fig. 12A). Body elongated ovoid, with ventral side flattened. Six pairs of 
tube feet on the posterior half of the flattened ventral sole. Three pairs of papillae are present on the dorsal side, two pairs on the anterior part of the body and one pair on the posterior part. Ten tentacles surrounding the mouth (Fig. 12B), each divided into six to eight marginal lobes. Tentacles spicules curved rods with spines $(130-300 \mu \mathrm{m})$ at their ends and in the middle on the external side of the curve (Fig. 12C). Calcareous ring with five interlinked pieces, usually visible by transparency. Each piece has four pair of arms radiating from the centre (Fig. 12D). Arched rods with one or two spines and four spiny leg ossicles (Fig. 12E, F). Papillae spicules smooth rods (Fig. 12G). Marenzeller (1893) reports males and females, describing gonads as one tuft slender and ramified for males and short and less ramified for females.

Distribution: Endemic to the Mediterranean Sea (Pagés et al. 2007, Gebruk et al. 2013).

Depth range: 755-4766 m (Fiege and Liao 1996).

Remarks: Penilpidia ludwigi has been reported twice in the eastern Mediterranean Sea basin (Marenzeller 1893, Fiege and Liao 1996) at depths of 755 to $4766 \mathrm{~m}$. Its presence was reported in the northwestern Mediterranean Sea from sediment traps at $22 \mathrm{~m}$ above the bottom at depths between 1200 and $1700 \mathrm{~m}$ in the Palamós Canyon (Pagés et al. 2007). Although a speci- men has been reported from a depth of only $48 \mathrm{~m}$ on the southwestern coast of Portugal (Cunha de Jesus and Cancela da Fonseca 1999), there is some doubt about this identification owing to depth (very shallow) and substrate (i.e. rocky area), as well as the poor condition of the specimen. Gebruk et al. (2008, 2013) described a related species in the North Atlantic and included a re-description of the genus and its species.

\section{Order DACTYLOCHIROTIDA}

Pawson and Fell (1965)

Family YPSILOTHURIIDAE Heding, 1942

Genus Ypsilothuria E. Perrier, 1886

Ypsilothuria bitentaculata (Ludwig, 1893)

(Fig. 13)

Sphaerothuria bitentaculata Ludwig, 1893:184. 1894: 141 pl. 12-14.

Ypsilothuria bitentaculata attenuata Alvà, 1991: 459-460.

Material: 27 specimens collected during cruises PROMETEO 01 to 05, PROMARES and DOSMARES 01. Depth of occurrence: $900 \mathrm{~m}$ to $1350 \mathrm{~m}$. Zone: western Mediterranean Sea open slope (Table 2).

Description: Typically U-shaped (Fig. 13A). Two opposite siphons, oral and anal. Body wall thorny due to the presence of intricate scales, also visible with naked eye. Eight digitiform tentacles, of very unequal size, one on each side, being larger than the others. Calcareous plates visible with naked eye (Fig. 13B).
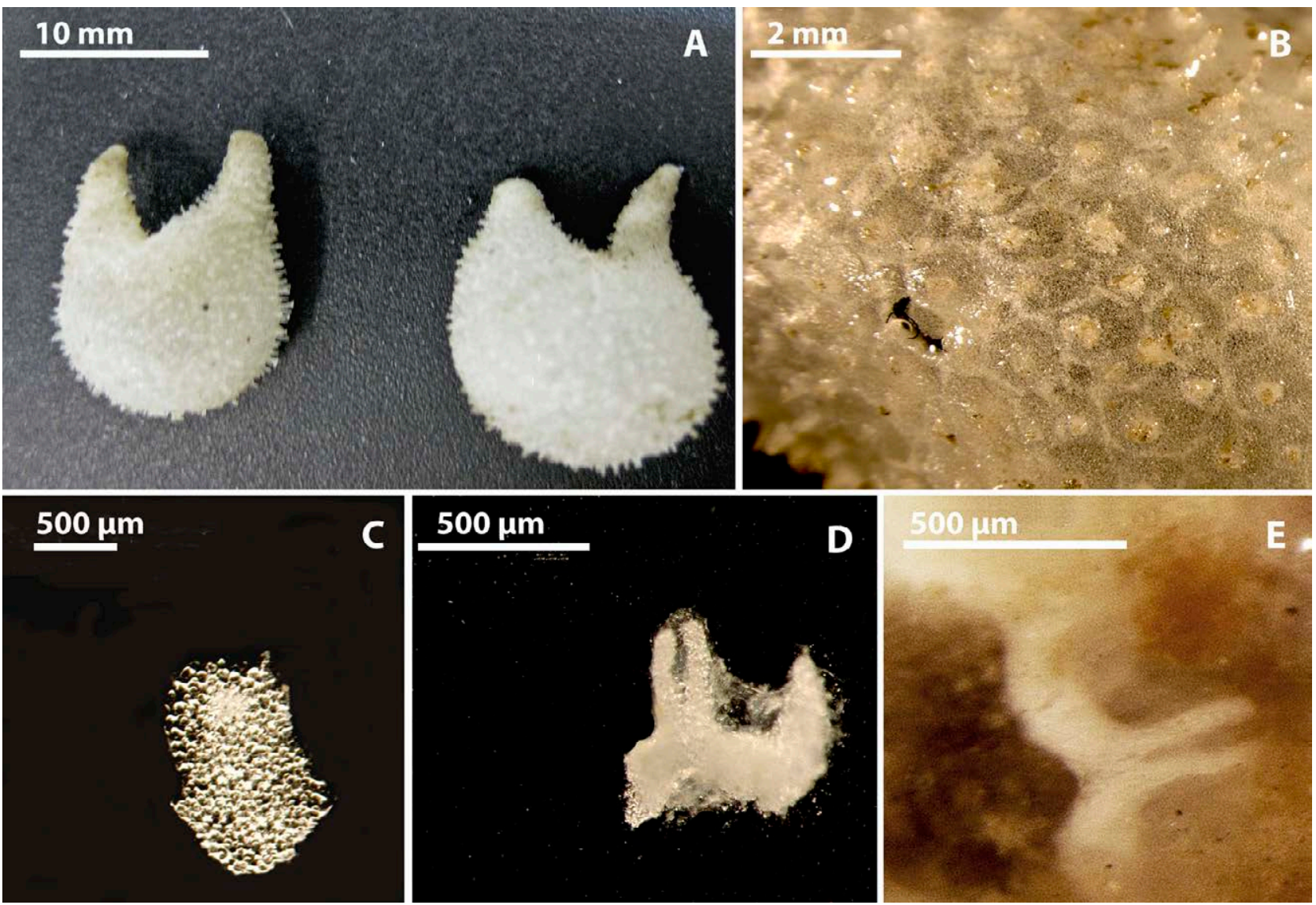

Fig. 13. - Ypsilothuria bitentaculata characteristics. A, general view; B, plates from skin; C, calcareous plate detail with central spine; D, E, calcareous ring detail of bifurcated projections. 
Plates subcircular. Strong short spire placed near the edge of the plate (Fig. 13C). The plates are perforated by many small holes giving an irregular shape. Calcareous deposits in tentacles. Calcareous ring with eight plates. Lateral interradial plates with anterior bifurcated projections (Fig. 13D, E). The projections are often asymmetric. 1978).

Distribution: Cosmopolitan (Cherbonnier and Féral

Depth range: 225-4440 m (Cherbonnier and Féral 1978). Mediterranean Sea depth range 900 to $1560 \mathrm{~m}$ (Alvà 1991).

Remarks: Differs from Y. talismani in the bifurcated projections of the calcareous ring and the size of the plates (Gage et al. 1985, Alvà 1991).

\section{Taxonomic information on deep-sea Mediterranean echinoderms}

Fifty species of echinoderms present in the Mediterranean Sea and cited in the literature as presenting maximum depth of occurrence below $800 \mathrm{~m}$ were grouped in a table (Table 3 ). After carefully analysing all published data, we observed that from the initial 50 species shown in Table 3 only 29 were signalled at depths below $800 \mathrm{~m}$ depth in the Mediterranean Sea. Geographically, five of the studied species in Table 3 were endemic to the Mediterranean. Three were cosmopolitan and one had a broad Indo-Pacific and Mediterranean distribution (while all the other species had an Atlanto-Mediterranean distribution). Of the 50 species, 11 were sampled in our study. One of them was a first record for the Mediterranean. Four of the sampled species increased their maximum depth of distribution, and one increased the maximum depth of distribution in the Mediterranean Sea.

\section{DISCUSSION}

\section{General remarks}

This study provides a thorough review of all citations and distribution information of deep-sea echinoderms in the Mediterranean Sea. The literature review showed that for some species only very limited biological/ecological data were available, and in many cases only species lists were provided (Tortonese 1979, Pérez-Ruzafa and López-Ibor 1988). This paper provides new information of specimens collected in the last few years, including new records and extensions of geographic and bathymetric distributions. Our new data include information from areas with complex topography such as canyons, which previously have been sampled inadequately. We have collected together information of echinoderms living deeper than $800 \mathrm{~m}$.

Our results report, for the first time, the presence of the echinoid Gracilechinus elegans (Düben and Koren, 1844 ) in the Mediterranean Sea. In addition, there are new records of two species considered previously as "rare" in the Mediterranean Sea. At present, there is no consensus regarding what determines a "rare species" (Cunningham and Lindenmayer 2005). In our study, taking into account all published information, we considered "rare" those species that have been reported less than five times in the whole basin. Based on this, two "rare" holothurians endemic to the Mediterranean Sea, Hedingia mediterranea (Bartolini Baldelli, 1914) Tortonese, 1965 and Penilpidia ludwigi (von Marenzeller, 1893), were identified. Additionally, we note greater bathymetric ranges for four species. The depth range of the asteroid Ceramaster grenadensis (Perrier, 1881), previously dredged in the Mediterranean Sea down to $2400 \mathrm{~m}$ (Carpine 1970, Tortonese 1979, Alvà 1987a), was extended to $2845 \mathrm{~m}$. The echinoid Brissopsis lyrifera (Forbes, 1841), previously dredged around $1500 \mathrm{~m}$ (Sibuet 1974, Tortonese 1979, Cartes et al. 2009), was extended to $2250 \mathrm{~m}$. Parezan (1970) reported the presence of $B$. lyrifera at $2500 \mathrm{~m}$ depth in the Ionian Sea. However, the specimen reported by Parezan (1970) was the test of a dead animal. Consequently later studies have not reported the presence of $B$. lyrifera at depths greater than $1500 \mathrm{~m}$. The holothurian Hedingia mediterranea had been dredged previously only around $1000 \mathrm{~m}$ (Bartolini Baldelli 1914). Our data extend its bathymetric distribution range to $1500 \mathrm{~m}$. Finally, the depth range of Holothuria (Panningothuria) forskali Delle Chiaje, 1823, which had been dredged previously down to $348 \mathrm{~m}$ in the Atlantic Ocean and around $193 \mathrm{~m}$ in the Mediterranean Sea (Pérez Ruzafa et al. 1987), is extended to $850 \mathrm{~m}$ in the Mediterranean Sea.

Below, we discuss the results by class. At the beginning of each section, if appropriate, we discuss first any new records and those of rare species. We then compare our results with the published literature, as detailed in Table 3.

\section{Class Asteroidea}

Our results for the class Asteroidea were based on two typical bathyal species, Hymenodiscus coronata (G.O. Sars, 1872) and Ceramaster grenadensis (Perrier, 1881). The depth range of $C$. grenadensis has been expanded to $2845 \mathrm{~m}$. Where their depth ranges overlapped (1500 to $2250 \mathrm{~m}$ ) the two species co-occurred, perhaps facilitated by their contrasting diets: $H$. coronata is a suspension feeder and $C$. grenadensis a secondary consumer (Carlier et al. 2009).

Other deep-sea asteroids reported previously from the Mediterranean at depths greater than $800 \mathrm{~m}$ (Table 3), such as Astropecten irregularis irregularis (Pennant, 1777), Luidia sarsi sarsi Düben and Koren, in Düben, 1845, Odontaster mediterraneus (Marenzeller, 1893), Henricia cylindrella (Sladen, 1883) and Plutonaster bifrons (W. Thompson, 1873), were not sampled in the recent work. Plutonaster bifrons was reported by Tortonese (1979) at $2715 \mathrm{~m}$. However, this depth distribution was not supported by the specific data or citations in Tortonese's publication. Thus, we consider the Plutonaster bifrons sample of the "Pola" (Marenzeller 1893) to be the deepest known record of 
296 - A. Mecho et al.

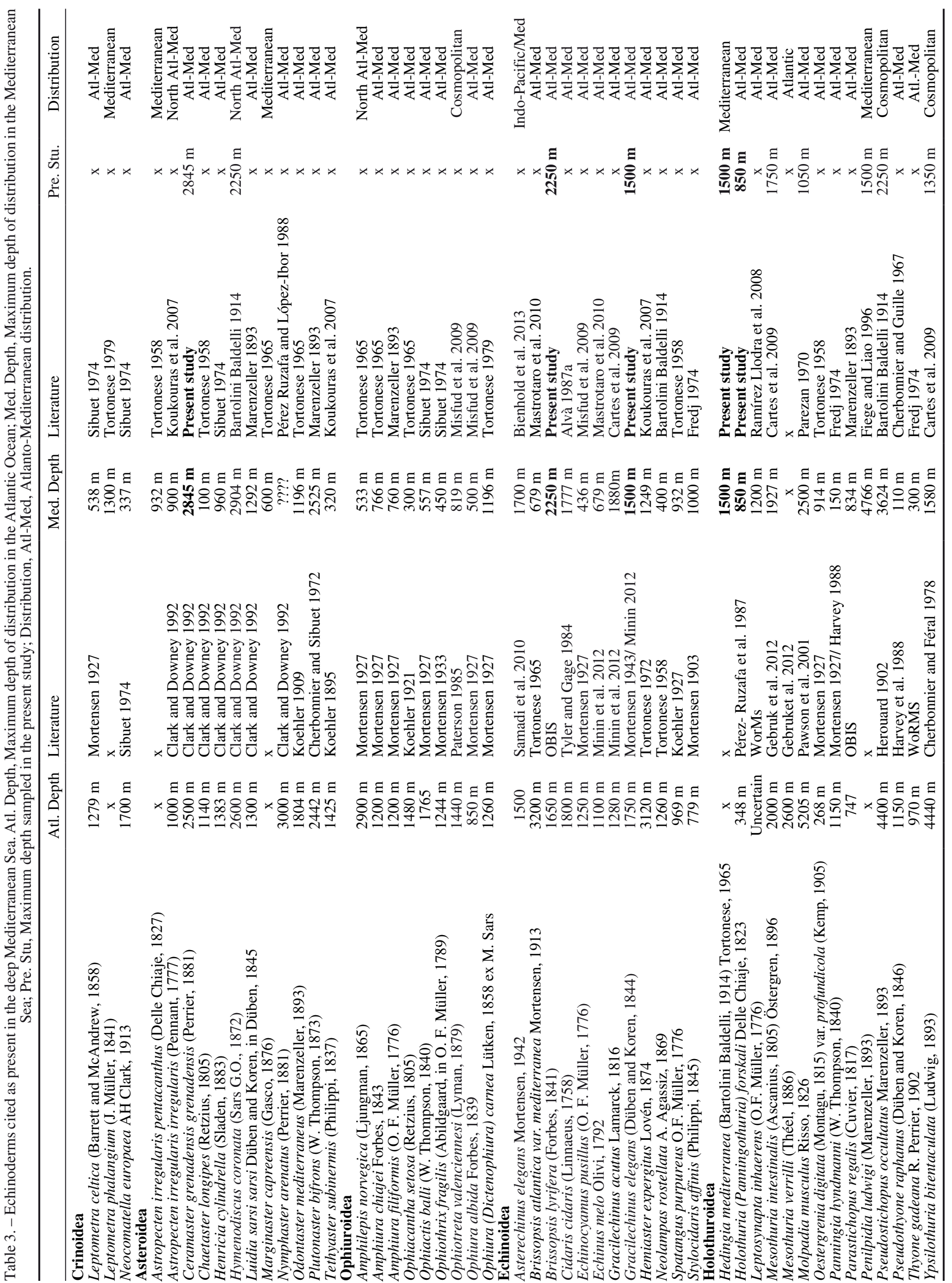


P. bifrons $(2525 \mathrm{~m})$, in agreement with other authors (Alvà 1987a, Koukouras et al. 2007). Two other asteroid species, Marginaster capreensis (Gasco, 1876) and Astropecten irregularis pentacanthus (Delle Chiaje, 1827), have been considered to be Atlanto-Mediterranean species. Both species were reviewed by Clark and Downey (1992), who considered them to be endemic to the Mediterranean Sea. Astropecten irregularis pentacanthus (Delle Chiaje, 1827) was cited by Tortonese $(1958,1965)$ at $932 \mathrm{~m}$ depth from the "Pola" cruise. Two other species with a maximum depth of distribution at 1000-1500 $\mathrm{m}$ in the Atlantic Ocean, Chaetaster longipes (Retzius, 1805) and Tethyaster subinermis (Philippi, 1837), occurred considerably shallower (100 and $320 \mathrm{~m}$, respectively) in the Mediterranean Sea. Finally, Nymphaster arenatus (Perrier, 1881), with a maximum depth at $3000 \mathrm{~m}$ in the Atlantic Ocean, has been cited from the Mediterranean Sea by PérezRuzafa and López-Ibor (1988) and Koukouras (2007), but no depth data were given.

\section{Class Echinoidea}

This study reports for the first time the presence of Gracilechinus elegans (Düben and Koren, 1844) in the Mediterranean Sea. While Mortensen (1903) reported this species from the Mediterranean, he discarded the record in a later publication (Mortensen 1943). The lack of observations of G. elegans in the Mediterranean Sea could be caused by misidentification of congeneric species. For instance, adults of $G$. elegans are similar to juveniles of $G$. alexandri (see $G$. elegans description above). The only specimen of $G$. alexandri reported from the Mediterranean Sea (Alva 1987b) was not available for comparison. Another species that could lead to misidentification in the Mediterranean Sea is Gracilechinus acutus var. norvegicus (Düben and Koren, 1844). The possibility of hybridization between species should be taken into account. Hybridization has been described for other species of the same genus in the Atlantic (Shearer et al. 1911). Hybrids themselves may be responsible for some failures in identification. Molecular studies of Mediterranean Sea and Atlantic Ocean specimens may be able to determine the species more clearly in the future, including hybridization and phylogenetic differences.

Brissopsis lyrifera was present in canyon muddy sediments below $900 \mathrm{~m}$, as suggested originally by Carpine (1970). Large and dense aggregations of dead and live Brissopsis were observed by ROV in canyons. The gregarious behaviour of this species has been reported in previous studies (Laubier and Emig 1993, Ramírez-Llodra et al. 2008). Many echinoid tracks were visible on the sediment, suggesting a "herd" in movement, similar to what has been observed for other bathyal echinoids (Salazar 1970, Gage and Tyler 1991). Although the number of collected specimens was too low to conduct population structure analyses, we observed that smaller specimens appeared to occur at greater depths. This contrasts with the results of Ferrand et al. (1988), who proposed the recruitment of smaller individuals at shallower depths. Our results are in agreement with Harvey et al. (1988), who suggested a possible 'dwarfism' for this species at greater depths. Brissopsis lyrifera is usually reported from the upper slope (250-400 m depth) on the Mediterranean continental margin (Tortonese 1965, Carpine 1970, Ferrand et al. 1988, Koukouras et al. 2007, Ramírez-Llodra et al. 2008, Cartes et al. 2009). The abundance of this species has decreased greatly in recent years on the upper and middle continental slopes at depths down to 1000 $\mathrm{m}$ (Mecho, pers. obs.), which may be related to intensive commercial trawling activity down to depths of 900 m (Ramírez-Llodra et al. 2010, Puig et al. 2012). Local fishermen have noted a large decrease in $B$. lyrifera in their by-catch in the last decade.

No specimens of the closely related species Brissopsis atlantica var. mediterranea Mortensen, 1913 were found.

Eight other species of echinoids have been reported from the Mediterranean Sea at depths below $800 \mathrm{~m}$ (Table 3). Two of these species, Stylocidaris affinis (Philippi, 1845) and Cidaris cidaris (Linnaeus, 1758), are common in the deep sea and have been sampled frequently below $800 \mathrm{~m}$ in the Mediterranean Sea (Alvà 1987a, Cartes et al. 2009). However, these two species were absent from our samples. Other species that occur mainly at shallower depths, such as Spatangus purpureus O.F. Müller, 1776 and Gracilechinus acutus Lamarck, 1816, were also not sampled in the recent cruises, even though they have been reported previously at depths greater than $800 \mathrm{~m}$.

Two deep "rare echinoid species" are reported in the literature from the Mediterranean Sea: Hemiaster expergitus Lovén, 1874, sampled only three times (Cherbonnier 1958, Tortonese 1972, Koukouras et al. 2007) and Asterechinus elegans Mortensen, 1942, an Indo-Pacific species recently found in the eastern Mediterranean in association with sunken wood (Bienhold et al. 2013). These two species were not sampled in the present study. Three other species, Echinocyamus pusillus (O. F. Müller, 1776), Echinus melo Olivi, 1792, and Neolampas rostellata A. Agassiz, 1869, have maximum depths of distribution at $1100 \mathrm{~m}$ in the Atlantic Ocean. Their maximum depths of distributions are shallower (not exceeding $700 \mathrm{~m}$ depth) in the Mediterranean Sea.

\section{Class Holothuroidea}

The holothurian Hedingia mediterranea was first described by Bartolini Baldelli (1914) in the Tyrrhenian Sea. Its presence has not been reported since in the Mediterranean. It is possible that specimens reported as $H$. mediterranea have been misclassified as sipunculids because of the similar body shape of the two groups. Some studies have cited $H$. mediterranea as endemic to the Mediterranean Sea (Koehler 1921, 1927, Tortonese 1963, 1965, Parenzan 1970, Fredj 1974, Koukouras et al. 2007, Matarrese 2010), but only by referring to the original record of the type specimen. Accordingly, we consider the individuals sampled in this study as a truly 'rediscovered' species and extending both its geographic range to the northwestern Mediterranean 
Sea and its bathymetrical distribution. One sample collected in the Blanes Canyon at $1200 \mathrm{~m}$ included four individuals and another at $1500 \mathrm{~m}$ in the same area included five individuals, suggesting a greater presence of this species in canyons. Pawson et al. (2001) considered the Bartolini Baldelli specimen as Hedingia albicans (Théel, 1886) Deichmann, 1938. This species is known from several locations in the North Atlantic. However, no explanation was provided for the synonymy of $H$. albicans and $H$. mediterranea. The information available does not allow us to clarify whether the Mediterranean specimens (classified as Hedingia mediterranea) are the same species as or distinct from the Atlantic species (classified as Hedingia albicans). In the present study we continue to classify the species as $H$. mediterranea following Tortonese $(1963,65)$. A molecular comparison between species of Hedingia would help to resolve the taxonomic discrepancies.

The only species of Elpidiidae present in the Mediterranean Sea is Penilpidia ludwigi. This is also considered to be a "rare" species, because it has been reported only three times previously, twice from the eastern Mediterranean Sea (Marenzeller 1893, Fiege and Liao 1996) and once from the deep western Mediterranean Sea (Pagés et al. 2007). However, when it does occur it may be found in abundance. Pagés et al. (2007) collected 150 individuals. More than 200 individuals were collected in one epibenthic sledge sample, suggesting that the species may occur in dense aggregations (Fiege and Liao 1996, Pagés et al. 2007) similar to those reported for other Elpidiidae in the Atlantic Ocean (Billett and Hansen 1982, Billett et al. 2001, 2010, Gebruk et al. 2003, Ruhl and Smith 2004). The presence of $P$. ludwigi in the Blanes Canyon sediment traps adds new faunistic records for this area. Pagés et al. (2007) collected P. ludwigi in the Palamós Canyon also with sediment traps moored at $22 \mathrm{~m}$ above the bottom. Our sediment traps sampled greater numbers in autumn and winter, coinciding with a stormy period in the northwestern Mediterranean (Sanchez-Vidal et al. 2012). This may have resulted in greater resuspension of bottom sediments and associated small fauna, such as $P$. ludwigi. Another factor that can cause resuspension of sediments, and thus the collection of small holothurians in sediment traps, are deep currents (Gebruk et al. 2013). In addition, swimming behaviour has been described in other Elpidiidae (Ohta 1985, Pawson and Foell 1986, Miller and Pawson 1990) and has also been proposed for P. ludwigi (Pagés et al. 2007). Swimming cannot be discarded as an explanation of the presence of this species in sediment traps. Pagés (2007) suggested that aggregations of $P$. ludwigi might occur during periods coincident with phytoplankton spring blooms and the flux of new organic matter to the seafloor. Although our sediment traps sampled greater numbers of specimens in autumn (similarly to the epibenthic sledge sample) and winter, these seasonal peaks of abundance may also indicate periodic recruitment of opportunistic species, as reported for other small species of Elpidiidae (Billett and Hansen 1982, Ohta 1985, Billett 1991, Billett et al. 2001, 2010).

The class Holothuroidea was the most speciose and most abundant of all the groups collected in our sam- ples, as in the North Atlantic deep sea (Billett 1991, Gage and Tyler 1991). The order Aspidochirotida had the greatest number of species. Unlike in other studies, we did not observe dense aggregations of Mesothuria (Allantis) intestinalis (Ascanius, 1805) Östergren, 1896, as reported by Cartes et al. (2009) from $1600 \mathrm{~m}$ in the same region. Another species of the same genus, Mesothuria verrilli (Théel, 1886), has been reported from the Mediterranean Sea (Koukouras et al. 2007), but the presence of this species in the Mediterranean Sea was reviewed and discarded by Gebruk et al. (2012). Pseudostichopus occultatus Marenzeller 1893, a cosmopolitan aspidochirotid species, showed a restricted geographic and bathymetric distribution in our samples, occurring only between 2000 and $2200 \mathrm{~m}$ on the open slope, but in very high abundances.

The presence of large aggregations of individuals near the canyon axis could be related to food inputs (Morgan and Neal 2012). Submarine canyons act as conduits of organic matter from the shelf to bathyal/ abyssal depths (Company et al. 2012). The aggregations of $P$. occultatus may be due to the periodic changes in food availability originating from canyon refluxes, as proposed for Mesothuria. To the best of our knowledge, the presence of Holothuria (Panningothuria) forskali Delle Chiaje 1823 at mid-bathyal depths has not been reported previously. The deepest records were at $345 \mathrm{~m}$ off the Canary Islands (Pérez Ruzafa et al. 1987, Hernández et al. 2013). The specimen sampled in the present study came from the Blanes Canyon at $850 \mathrm{~m}$ depth.

Two species of the order Molpadiida were collected. Molpadia musculus Risso, 1826 was present only in open slope areas. Hedingia mediterranea occurred mainly in canyon areas. Both species are deposit feeders and live infaunally. Molpadia musculus was reported as a typical canyon species in the Atlantic Ocean (Amaro et al. 2009) and in other Mediterranean Sea areas (Ramírez-Llodra et al. 2008, Cartes et al. 2009). However, no specimens of M. musculus were found in our canyon samples. The high presence of $H$. mediterranea inside canyons suggests habitat specialization, but further sampling inside canyons is necessary to confirm this hypothesis.

The order Dactylochirotida was represented by a single species, Ypsilothuria bitentaculata (Ludwig, 1893). The presence of this species only at middle slope depths is commonly reported (Pawson 1965, Gage et al. 1985). This species was reported from the Mediterranean Sea only in the early 1990s (Alvà 1991). Subsequently, Ypsilothuria bitentaculata has been cited by other authors (Massin 1996, Cartes et al. 2009) and also as Y. talismani by Ramírez-Llodra et al. (2008). Little information is available for Ypsilothuria in the Mediterranean Sea. A detailed discussion on its taxonomy must await further sampling.

Of the holothurians species reported previously from the deep (occurrence below $800 \mathrm{~m}$ ) Mediterranean Sea, only two species did not occur in our study (Table 3). First, Leptosynapta inhaerens (O.F. Müller, 1776) occurs at shallower depths of around $500 \mathrm{~m}$. A record of this species by Ramírez-Llodra et al. (2008) 
from $1200 \mathrm{~m}$ on the Catalan margin off Barcelona is uncertain and may have been misidentified (Company, pers. com). Second, Oestergrenia digitata (Montagu, 1815) var. profundicola (Kemp, 1905) has been reported at $900 \mathrm{~m}$ (Marenzeller 1893, Tortonese 1958). One species typical of shallower Mediterranean waters, Parastichopus regalis (Cuvier, 1817), has been cited at $834 \mathrm{~m}$ depth by Marenzeller (1893), but no other reports are known for these depths. Finally, there are three other species, Panningia hyndmanni (W. Thompson, 1840), Pseudothyone raphanus (Düben and Koren, 1846) and Thyone gadeana Perrier R., 1898, which have maximum depth ranges extending to around 1000 $\mathrm{m}$ in the Atlantic Ocean but occur no deeper than 300 $m$ in the Mediterranean Sea.

\section{Class Crinoidea}

Crinoids were totally absent from our samples. Three species of crinoids have been cited from the bathyal Mediterranean seafloor (Table 3). Only one of them, the endemic crinoid Leptometra phalangium (J. Müller, 1841), has a maximum depth of distribution greater than $800 \mathrm{~m}$. Stalked crinoids were not reported in the Mediterranean Sea (David et al. 2006).

There are some records of high abundances of Leptometra phalangium in upper slope areas (100 to 400 m depth) (Pérès and Picard 1956a, Mifsud et al. 2009), as observed for the same genus in other areas (Fonseca et al. 2013). The deepest record for this species is 1292 m (Marenzeller 1893). However, despite these deeper records, not a single crinoid was collected in any of our hauls or observed during the ROV dives. Their occurrence at predominantly shallower depths (Hellal 2012) may explain the absence of these crinoids in our samples.

\section{Class Ophiuroidea}

Ophiuroids were also totally absent from our samples. Nine species of ophiuroids have been cited previously from the Mediterranean Sea at depths between 300 and $1219 \mathrm{~m}$ (Table 3), with only two species, Ophiura (Dictenophiura) carnea Lütken, 1858 ex M. Sars, and Ophiotreta valenciennesi (Lyman, 1879), cited below $800 \mathrm{~m}$ (Tortonese 1979, Mifsud et al. 2009). All nine species have been reported from depths greater than $800 \mathrm{~m}$ in the Atlantic Ocean, but their maximum depth of distribution in the Mediterranean Sea is shallower. This may explain the lack of ophiuroids in our study.

\section{Endemicity in echinoderms from the Mediterranean}

There has been considerable debate as to whether the deep-sea fauna of the Mediterranean is truly endemic or is a sub-population of Atlantic species (Bouchet and Taviani 1992, Tyler 2003). The shallow Gibraltar Sill may be a significant barrier for the influx of larvae of echinoderms from the Atlantic and may act as an isolating mechanism once populations are established in the Mediterranean. The higher temperatures of deep water in the Mediterranean may mitigate the immigration of species from the deep Atlantic. However, an increased sampling effort and molecular analyses are required before this aspect is fully resolved. Our samples increase the availability of genetic data necessary for future comparative studies between populations.

\section{ACKNOWLEDGEMENTS}

The authors would like to thank the Officers and Crews of the R/V García del Cid and R/V Sarmiento de Gamboa and the scientific parties of the BIOFUN, PROMETEO and DOSMARES cruises for their contributions at sea. We would like to thank Dr. Daniel Martin and Mrs. Marta Segura (CEAB-CSIC) for the sediment trap samples and Dr. Craig Young for his help in the classification of G. elegans. The authors acknowledge the Biodiversity Heritage Library (http:// www.biodiversitylibrary.org/) for making ancient biodiversity literature openly available. This study was funded by the PROMETEO project (CTM200766316-C02/MAR, CICYT), the BIOFUN project (CTM2007-28739-E, European Science Foundation and national funding agencies) and the DOSMARES project (CTM2010-21810-C03-03). ERLL was funded by a JAE-DOC postdoctoral grant (CSIC, Spain) with co-funding from the European Social Fund. JA is a fellow of the Ramón y Cajal Programme (MICINN).

\section{REFERENCES}

Aguzzi J., Bahamon N., Marotta L. 2009. The influence of light availability and predatory behavior of the decapod crustacean Nephrops norvegicus on the activity rhythms of continental margin prey decapods. Mar. Ecol. 30: 366-375. http://dx.doi.org/10.1111/j.1439-0485.2008.00276.x

Alvà V. 1987a. Equinodermos batiales de la cubeta catalano-balear (Mediterráneo noroccidental). Misc. Zool. 11: 211-219.

Alvà V. 1987b. Presencia en el Mediterráneo del equinoideo batial Echinus alexandri (Danielssen y Koren, 1883) (Echinodermata, Echinoidea). Pub. Dep. Zool. Univ. Barcelona 13: 93-97.

Alvà V. 1991. On three species of Mediterranean echinoderms. Sci. Mar. 55: 459-462.

Amaro T., Witte H., Herndl G.J. et al. 2009. Deep-sea bacterial communities in sediments and guts of deposit-feeding holothurians in Portuguese canyons (N.E. Atlantic). Deep-Sea Res. Part II. 56: $1834-1843$. http://dx.doi.org/10.1016/j.dsr.2009.05.014

Bahamon N., Sarda F., Aguzzi J. 2009. Fuzzy diel patterns in catchability of deep-water species on the continental margin. ICES J. Mar. Sci. 66: 2211-2218. http://dx.doi.org/10.1093/icesjms/fsp190

Bartolini Baldelli C. 1914. Asteroidi, ofiuroidi, crinoidi, oloturoidi raccolti nel Mediterraneo dalla RN. Washington (1881-1882). Vol. 7: 81-113.

Bienhold C., Pop Ristova P., Wenzhöfer F. et al. 2013. How deepsea wood falls sustain chemosynthetic life. PLoS One 8: e53590. http://dx.doi.org/10.1371/journal.pone.0053590

Billett D.S.M. 1991. Deep-sea holothurians. Oceanogr. Mar. Biol. Annu. Rev. 29: 259-317.

Billett D.S.M., Hansen B. 1982. Abyssal aggregations of Kolga hyalina Danielssen and Koren (Echinodermata:Holothurioidea) in the northeast Atlantic Ocean: a preliminary report. Deep-Sea Res. 29: 799-818. http://dx.doi.org/10.1016/0198-0149(82)90047-4

Billett D.S.M., Bett B.J., Rice A.L. et al. 2001. Long-term change in the megabenthos of the Porcupine Abyssal Plain (NE Atlantic). Prog. Oceanogr. 50: 325-348. http://dx.doi.org/10.1016/S0079-6611(01)00060-X

Billett D.S.M., Bett B.J., Reid W.D.K. et al. 2010. Long-term 
change in the abyssal NE Atlantic: The "Amperima Event" revisited. Deep-Sea Res. Part II. 57: 1406-1417. http://dx.doi.org/10.1016/j.dsr2.2009.02.001

Bolam S.G., Fernandes T.F., Huxham M. 2002. Diversity, biomass, and ecosystem processes in the marine benthos. Ecol. Monogr. 72: 599-615.

http://dx.doi.org/10.1890/0012-9615(2002)072[0599:DBAEPI 12.0.CO;2

Borrero Perez G., Benavides-Serrato M., Solano O. 2003. Holothuroideos (Echinodermata: Holothuroidea) recolectados en el talud continental superior del Caribe colombiano. Bol. Inst. Ocenogr. Venezuela Univ. Oriente 42: 65-85

Bouchet P., Taviani M. 1992. The Mediterranean deep-sea fauna: pseudopopulations of Atlantic species? Deep-Sea Res. Part A. 39: 169-184. http://dx.doi.org/10.1016/0198-0149(92)90103-Z

Carlier A., Le Guilloux E., Olu K. et al. 2009. Trophic relationships in a deep Mediterranean cold-water coral bank (Santa Maria di Leuca, Ionian Sea). Mar. Ecol. Prog. Ser. 397: 125-137. http://dx.doi.org/10.3354/meps08361

Carpine C. 1970. Écologie de l'étage bathyal dans la Méditerranée occidentale. Mem. Inst. Oceanogr. Monaco 2: 1-146.

Cartes J.E., Maynou F., Fanelli E. et al. 2009. The distribution of megabenthic, invertebrate epifauna in the Balearic Basin (western Mediterranean) between 400 and $2300 \mathrm{~m}$ : Environmental gradients influencing assemblages composition and biomass trends. J. Sea Res. 61: 244-257 http://dx.doi.org/10.1016/j.seares.2009.01.005

Cherbonnier G., Féral J.P. 1978. Echinodermes : Holothuries Résultats des Campagnes MUSORSTOM 1 - PHILIPPINES. Resultat des campagnes Musostorm: 358-412.

Cherbonnier G., Guille A. 1967. Complément à la faune des échinodermes de la mer de Banyuls. Vie Millieu 18: 317-330.

Cherbonnier G., Sibuet M. 1972. Résultats scientifiques de la campagne Noratlante: Astérides et Ophiurides. Bull. Mus. Hist. Natl. Paris 3: 1333-1394.

Cherbonnier G. 1958. Echinodermata. Faune marine des PyrénéesOrientales Vol. 2. Université de Paris, Paris, 67 pp.

Clark A.M., Downey M.E. 1992. Starfishes of the Atlantic. Chapman and Hall, London, 794 pp.

Coll M., Piroddi C., Steenbeek J. et al. 2010. The Biodiversity of the Mediterranean Sea: Estimates, Patterns, and Threats. PLoS One 5 (8): e11842. http://dx.doi.org/10.1371/journal.pone.0011842

Company J.B., Maiorano P., Tselepides A., Plaity W., Politou C.Y., Sardà F., Rotllant G. 2004. Deep-sea decapod crustaceans in the western and central Mediterranean Sea: preliminary aspects of species distribution, biomass and population structure. Sci. Mar. 68: 73-86.

Company J.B., Ramirez-Llodra E., Sardà F. et al. 2012. Submarine canyons in the Catalan Sea (NW Mediterranean): megafaunal biodiversity patterns and anthropogenic threats. In: IUCN (eds), Mediterranean submarine canyons: Ecology and governance. IUCN, Gland (Switzerland) and Malaga (Spain), pp. 133-144.

Cunha de Jesus D., Cancela da Fonseca L. 1999. First records of 13 echinoderm species on the southwest coast of Portugal. Bol. Inst. Esp. Oceanogr. 15: 343-349.

Cunningham R.B., Lindenmayer D.B. 2005. Modeling count data of rare species:some statistical issues. Ecology 86: 1135-1142. http://dx.doi.org/10.1890/04-0589

D’Onghia G., Mastrototaro F., Matarrese A. et al. 2003. Biodiversity of the upper slope demersal community in the eastern Mediterranean: Preliminary comparison between two areas with and without trawl fishing. J. Northwest. Atl. Fish. Soc. 31: 263-273.

Danovaro R., Pusceddu A. 2007. Ecomanagement of biodiversity and ecosystem functioning in the Mediterranean Sea: concerns and strategies. Chem. Ecol. 23: 347-360. http://dx.doi.org/10.1080/02757540701653384

Danovaro R., Company J.B., Corinaldesi C. et al. 2010. Deep-Sea Biodiversity in the Mediterranean Sea: The Known, the Unknown, and the Unknowable. PLoS One 5 (8): e11832. http://dx.doi.org/10.1371/journal.pone.0011832

David J., Roux M., Messing C.G. et al. 2006. Revision of the pentacrinid stalked crinoids of the genus Endoxocrinus (Echinodermata, Crinoidea), with a study of environmental control of characters and its consequences for taxonomy. Zootaxa 1156: $1-50$

Emig C.C. 1997. Bathyal zones of the Mediterranean continental slope: An attempt. Publ. Espec. Inst. Esp. Oceanogr. 23: 23-33.

Ferrand J.G., Vadon C., Doumenc D. et al. 1988. The effect of depth on the reproductive cycle of Brissopsis lyrifera (Echinoidea, Echinodermata) in the Gulf of Lions, Mediterranean Sea. Mar. Biol. 99: 387-392. http://dx.doi.org/10.1007/BF02112131

Fiege D., Liao Y. 1996. Penilpidia ludwigi (Marenzeller, 1893) (Holothuroidea: Elpidiidae) rediscovered from the Eastern Mediterranean Sea. Biosyst. Ecol. Ser. 11: 61-66.

Fonseca P., Abrantes F., Aguilar R. et al. 2013. A deep-water crinoid Leptometra celtica bed off the Portuguese south coast. Mar. Biodiv. 44: 223-228. http://dx.doi.org/10.1007/s12526-013-0191-2

Fredj G. 1974. Stockage et exploitation des données en écologie marine. Considération biogéographiques sur le peuplement benthique de la Méditerranée. Mem. Inst. Oceanogr. (Monaco) 7: $1-88$

Gage J.D., Tyler P.A. 1991. Deep-Sea Biology: A Natural History of Organisms at the Deep-Sea Floor. Press Syndicate of the University of Cambridge, Cambridge, 504 pp. http://dx doi org/10.1017/CBO9781139163637

Gage J.D., Billett D.S.M., Jensen M. et al. 1985. Echinoderms of the Rockall Trough and adjacent areas: Echinoidea and Holothurioidea. Bull. Br. Mus. (Nat. Hist.) Zool. 48: 173-213.

Galil B.S., Goren M. 1995. The deep sea Levantine Fauna. New records and rare occurrences. Senckenb. Marit. 25: 41-52.

Gebruk A.V. 2008. Holothurians (Holothuroidea, Echinodermata) of the northern Mid-Atlantic Ridge collected by the G.O. Sars MAR-ECO expedition with descriptions of four new species. Mar. Biodivers. Rec. 4: 48-60.

Gebruk A.V., Bluhm H., Soltwedel T. et al. 2003. A re-description of the enigmatic deep-sea holothurian Irpa abyssicola (Elpidiidae, Elasipodida) with remotely operated vehicle observations on benthic organisms in the Norwegian-Greenland Basin. Sarsia 88: 49-54. http://dx.doi.org/10.1080/00364820308470

Gebruk A.V., Solís-Marín F.A., Billett D.S.M. 2012. Review of the genus Zygothuria Perrier, 1898 and the Atlantic group of species of the genus Mesothuria Ludwig, 1894 (Synallactidae: Holothuroidea) with description of the new species Mesothuria milleri sp. nov. J. Nat. Hist. 1894: 265-348. http://dx.doi.org/10.1080/00222933.2011.638423

Gebruk A.V., Rogacheva A.V., Pawson D.L. et al. 2013. Penilidia desbarresi sp. nov. (Echinodermata: Holothuroidea: Elasipodida) from the upper slope of Newfoundland and re-description of P. ludwigi (von Marenzeller, 1893). Mar. Biodivers. Rec. 9: 1029-1036.

Halpern J.A. 1969. Biological Investigations of the deep sea.46. The genus Litonotaster (Echinodermata, Asteroidea). Proc. Biol. Soc. Washingt. 82: 129-142.

Halpern J.A. 1970. Goniasteridae (Echinodermata: Asteroidea) of the Straits of Florida. Bull. Mar. Sci. 20: 193-286.

Harvey R., Gage J.D., Billett D.S.M. et al. 1988. Echinoderms of the Rockall Trough and adjacent areas 3. Aditional Records. Bull. Br. Mus. (Nat. Hist.) Zool. 54: 153-198.

Hellal A.M. 2012. Taxonomic study on the feather stars (Crinoidea: Echinodermata) from Egyptian Red Sea coasts and Suez Canal, Egypt. Open J. Mar. Sci. 2: 51-57. http://dx.doi.org/10.4236/ojms.2012.22007

Hernández J.C., Clemente S., Tuya F. et al. 2013. Echinoderms of the Canary Islands, Spain. In: Alvarado J.J., Solis-Marin F.A. (eds), Echinoderm Research and Diversity in Latin America. Springer Berlin Heidelberg, pp. 471-510. http://dx.doi.org/10.1007/978-3-642-20051-9_15

Hérouard E. 1902. Holothuries provenant des campagnes de la Princesse Alice. Résultats des Campagnes Scientifiques Accomplies sur son Yacht par Albert Ier, Prince Souverain de Monaco (1892-1897). $61 \mathrm{pp}$

Hérouard E. 1923. Holothuries des Campagnes des Yachts Princesse-Alice et Hirondelle II. 180 pp.

Hyman L.H. 1955. The Invertebrates. Echinodermata. Mc.GrawHill, New York, 763 pp.

Koehler R. 1895. Résultats scientifiques de la campagne du "Caudan" dans le Golfe de Gascogne. Echinodermes. Annales de l'Université de Lyon. Paris, 740 pp.

Koehler R. 1909. Echinodermes provenant des Campagnes du Yacht Princesse-Alice (Astérie, Ophiuries, Échinides et Crinoïdes) Vol. 34: $462 \mathrm{pp}$.

Koehler R. 1921. Faune de France: Échinodermes. Librairie de la Faculte des Sciences. Paris, 216 pp.

Koehler R. 1927. Les Echinodermes des mers d'Europe. Doin, Paris, $339 \mathrm{pp}$. 
Koukouras A., Sinis A.I., Bobori D. et al. 2007. The echinoderm (Deuterostomia) fauna of the Aegean Sea, and comparison with those of the neighbouring seas. J. Biol. Res. 7: 67-92.

Lacour D., Néraudeau D. 2000. Évolution de la diversité des Brissopsis (Echinoida, Spatangoida) en Méditerranée depuis la «crise messinienne»: application paléoécologique aux $B$. lyrifera intragypses de Sorbas (SE Espagne). Geodiversitas 22: 509-523.

Laubier L., Emig C.C. 1993. La faune benthique profonde de Méditerranée. In : F.R. Della Croce (eds), Symposium Mediterranean seas 2000. Ist. Sci. Amb. Mar. S. Marguerita Ligure, pp. 397-424.

Levin L.A., Sibuet M., Gooday A.J. et al. 2010. The roles of habitat heterogeneity in generating and maintaining biodiversity on continental margins: an introduction. Mar. Ecol. 31: 1-5. http://dx.doi.org/10.1111/j.1439-0485.2009.00358.x

Marenzeller E. v. 1893. Berichte der Commission für Erforschung des östlichen Mittelmeeres. Zoologische Ergebnisse. 1. Echinodermen gesammelt 1890, 1891 und 1892. Denkschriften der kaiserlichen akademie der wissenschaften 5: 1-24.

Mastrototaro F., D’Onghia G., Corriero G. et al. 2010. Biodiversity of the white coral bank off Cape Santa Maria di Leuca (Mediterranean Sea): An update. Deep-Sea Res. Part II 57: 412-430. http://dx.doi.org/10.1016/j.dsr2.2009.08.021

Massin C. 1996. Holothuries (Echinodermata) récoltées sur le talus continental méditerranéen lors de la Campagne DEPRO 96. Mésogée 55: 43-48.

Matarrese A. 2010. Echinodermata. Biol. Mar. Mediterr. 17: 619-624.

Mecho A., Aguzzi J., Company J.B. et al. 2014. First in situ observations of the deep-sea carnivorous ascidian Dicopia antirrhinum Monniot C., 1972 in the Western Mediterranean Sea. Deep-Sea Res. Part I 83: 51-56. http://dx.doi.org/10.1016/j.dsr.2013.09.007

Mifsud C., Taviani M., Stöhr S. 2009. Remarks on Echinodermata from the South Central Mediterranean Sea based upon collections made during the MARCOS cruise. Mediterr. Mar. Sci. 10: 63-71. http://dx.doi.org/10.12681/mms.109

Miller J.E., Pawson D.L. 1990. Swimming sea cucumbers (Echinodermata: Holothuroidea): a survey, with analysis of swimming behavior in four bathyal species. Smithson. Contrib. Mar. Sci. 35: 1-16. http://dx.doi.org/10.5479/si.01960768.35.1

Minin K.V. 2012. Vertical trends in morphological variability of sea urchins of the genus Echinus from the Northeast Atlantic and Arctic. Paleontol. J. 46: 927-935. http://dx.doi.org/10.1134/S0031030112080096

Monniot F., Monniot C. 1975. Sept espèces d'Ascidies profondes de Méditerranée. Bull. Mus. Hist. Natl. Paris 330: 1117-1133.

Moranta J., Stefanescu C., Massutí E. et al. 1998. Fish community structure and depth-related trends on the continental slope of the Balearic Islands (Algerian basin, western Mediterranean). Mar. Ecol. Prog. Ser. 171: 247-259. http://dx.doi.org/10.3354/meps 171247

Morgan A., Neal L. 2012. Aspects of reproductive ecology and benthic-pelagic coupling in the sub-antarctic sea cucumber Pseudostichopus mollis (Theel). Cont. Shelf. Res. 43: 36-42. http://dx.doi.org/10.1016/j.csr.2012.04.013

Mortensen T. 1903. Echinoidea. The Danish Ingolf Expedition. The Zoological Museum of the University of Copenhagen, Copenhagen, $183 \mathrm{pp}$.

Mortensen T. 1927. Handbook of the Echinoderms of the British isles. Oxford University Press, Oxford, $471 \mathrm{pp}$.

Mortensen T. 1933. Ophiuroidea. The Danish Ingolf Expedition. The Zoological Museum of the University of Copenhagen, Copenhagen, 4(8), $121 \mathrm{pp}$.

Mortensen T. 1943. A Monograph of the Echinoidea. The Zoological Museum of the University of Copenhagen, Copenhagen, 3(2), 446 pp.

O'Loughlin P.M. 2002. Report on selected species of BANZARE and ANARE Holothuroidea, with reviews of Meseres Ludwig and Heterocucumis Panning (Echinodermata). Mem. Mus. Victoria 59(2): 297-325.

O’Loughlin P.M., Ahearn C. 2005. A review of pygal-furrowed Synallactidae (Echinodermata: Holothuroidea), with new species from the Antarctic, Atlantic and Pacific oceans. Mem. Mus. Victoria 62: 147-179.

O'Loughlin P.M., Paulay G. 2007. New Holothuria species from Australia (Echinodermata: Holothuroidea: Holothuriidae), with comments on the origin of deep and cool holothuriids. Mem. Mus. Victoria 64: 35-52.

Ohta S. 1985. Photographic observations of the swimming behavior of the deep-sea pelagothuriid holothurian Enypniastes (Elasipoda, Holothurioidea). J. Oceanogr. Soc. Japan 41: 121-133. http://dx.doi.org/10.1007/BF02109182

Pagés F., Martín J., Palanques A. et al. 2007. High occurrence of the elasipodid holothurian Penilpidia ludwigi (von Marenzeller, 1893 ) in bathyal sediment traps moored in a western Mediterranean submarine canyon. Deep-Sea Res. Part I 54: 2170-2180. http://dx.doi.org/10.1016/j.dsr.2007.09.002

Pancucci-Papadopoulou M.A., Murina G.V.V., Zenetos A. 1999. The Phylum Sipuncula in the Mediterranean Sea. Monogr. Mar. Sci. 2: 1-109.

Parenzan P. 1970. Esplorazione bentonica batiale e abissale dello Jonio. Thalassia Salentina 4: 7-39.

Paterson G.L.J. 1985. The deep-sea Ophiuroidea of the north Atlantic Ocean. Bull. Br. Mus. (Nat. Hist.) Zool. 49(1): 1-162.

Pawson D.L. 1965. The bathyal holothurians of the New Zealand region. Zool. Publ. Victoria Univ. Wellingt. 39: 1-33.

Pawson D.L., Foell E.J. 1986. Peniagone leander new species, an abyssal benthopelagic sea cucumber (Echinodermata: Holothuroidea) from the eastern central Pacific Ocean. Bull. Mar. Sci. 38: 293-299.

Pawson D.L., Vance D.J., Ahearn C. 2001. Western Atlantic sea cucumbers of the Order Molpadiida (Echinodermata: Holothuroidea). Bull. Biol. Soc. Washington 10: 311-327.

Pérès J.M. 1958. Trois plongées dans le canyon du Cap Sicié, effectuées avec le bathyscaphe FNRS III de la Marine Nationale. Bull. Inst. Oceanogr. Monaco 1115: 1-21.

Pérès J.M., Picard J. 1956a. Considérations sur l'étagement des formations benthiques. Recl. Trav. Stn. Mar. d'Endoume 18: 15-30.

Pérès J.M., Picard J. 1956b. Nouvelles observations biologiques effectuées avec le Bathyscaphe FNRS III et considérations sur le système aphotique de la Méditerranée. Bull. Inst. Oceanogr. Monaco 1075: 1-10

Pérez-Ruzafa A., López-Ibor A. 1988. Echinoderm fauna from the south-western Mediterranean. Biogeographic relationships. In: Burke R.D., Mladeno V.P., Parsley P.L et al. (eds), Echinoderm Biology. A. A. Balkema, Rotterdam, pp. 355-362.

Pérez Ruzafa A., Marcos C., Bacallado J.J. 1987. Presencia de Holothuria (Panningothuria) forskali (Echinodermata: Holoturoidea) en las Islas Canarias. Vieraea 17: 361-368.

Perrier E. 1898. Sur les Holothuries recueillies par le Travailleur et le Talisman. Comptes Rendus Académie Sciences 126: 1664-1666.

Puig P., Canals M., Company J.B. et al. 2012. Ploughing the deep sea floor. Nature 489: 286-289. http://dx.doi.org/10.1038/nature11410

Quetglas A., Carbonell A., Sanchez P. 2000. Demersal continental shelf and upper slope cephalopod assemblages from the Balearic Sea (North-Western Mediterranean). Biological aspects of some deep-sea species. Est. Coast. Shelf. Sci. 50: 739-749. http://dx.doi.org/10.1006/ecss.1999.0603

Ramírez-Llodra E., Tyler P.A. 2006. Echinus alexandri, Danielssen and Koren, 1883. In: Desbruyères D., Segonzac M., Bright M. (eds), Handbook of Deep-Sea Hydrothermal Vent Fauna. Denisia, Linz, pp. 544.

Ramírez-Llodra E., Ballesteros M., Company J.B. et al. 2008. Spatio-temporal variations of biomass and abundance in bathyal non-crustacean megafauna in the Catalan Sea (North-western Mediterranean). Mar. Biol. 153: 297-309. http://dx.doi.org/10.1007/s00227-007-0805-y

Ramírez-Llodra E., Company J.B., Sardà F. et al. 2010. Megabenthic diversity patterns and community structure of the Blanes submarine canyon and adjacent slope in the Northwestern Mediterranean: a human overprint? Mar. Ecol. 31: 167-182. http://dx.doi.org/10.1111/j.1439-0485.2009.00336.x

Reyss D. 1971. Les canyons sousmarins de la mer Catalane, le rech du Cap et le rech Lacaze-Dut- hiers. III. Les peuplements de macrofaune benthique. Vie Milieu 22: 529-613.

Riedl R. 1986. Fauna y flora del mar Mediterráneo. Ed. Omega, Barcelona, $858 \mathrm{pp}$.

Rinelli P. 1998. A synthesis of the Echinoderm fauna of the Tyrrhenian Sea. Rapp. CIESM 35: 485.

Ruhl H.A., Smith K.L. 2004. Shifts in deep-sea community structure linked to climate and food supply. Science 305: 513-515. http://dx.doi.org/10.1126/science.1099759

Salazar M.H. 1970. Phototaxis in the deep-sea urchin Allocentrotus 
fragilis (Jackson, 1912). J. Exp. Mar. Bio. Ecol. 5: 254-264. http://dx.doi.org/10.1016/0022-0981(70)90004-3

Samadi S., Corbari L., Lorion J. et al. 2010. Biodiversity of deepsea organisms associated with sunken-wood or other organic remains sampled in the tropical Indo-Pacific. Cah. Biol. Mar. 51: 459-466.

Sanchez-Vidal A., Canals M., Calafat A.M. et al. 2012. Impacts on the deep-sea ecosystem by a severe coastal storm. PLoS One 7: e30395. http://dx.doi.org/10.1371/journal.pone.0030395

Sardà F., Cartes J.E., Company J.B. 1994. Spatio-temporal variations in megabenthos abundance in three different habitats of the Catalan deep-sea (Western Mediterranean). Mar. Biol. 120: 211-219. http://dx.doi.org/10.1007/BF00349681

Sardà F., Cartes J.E., Company J.B. et al. 1998. A modified commercial trawl used to sample deep-sea megabentos. Fish Sci. 64: 492-493.

Sardà F., Calafat A., Flexas M. et al. 2004. An introduction to Mediterranean deep-sea biology. Sci. Mar. 68(Suppl. 3): 7-38.

Shearer C., De Morgan W., Fuchs H.M. 1911. Preliminary notice on the experimental hybridization of echinoids. J. Mar. Biol. Ass. U.K. 9: 121-144. http://dx.doi.org/10.1017/S0025315400073306

Sibuet M. 1974. Échinodermes de la mer d'Alboran. Bull. Mus. Hist. Natl. Paris 231: 25-34.

Sibuet M. 1979. Distribution and diversity of asteroids in atlantic abyssal basins. Sarsia 64: 85-91.

Tecchio S. Ramírez-Llodra E. Sardà F. et al. 2011a. Drivers of deep Mediterranean megabenthos communities along longitudinal and bathymetric gradients. Mar. Ecol. Prog. Ser. 439: 181-192.

http://dx.doi.org/10.3354/meps09333

Tecchio S., Ramírez-Llodra E., Sardà F. et al. 2011b. Biodiversity of deep-sea demersal megafauna in Western and Central Mediterranean basins. Sci. Mar. 75: 341-350.

http://dx.doi.org/10.3989/scimar.201175n2341

Tortonese E. 1954. Su alcune species di astropectinidae, con descrizione di un nuovo Astropecten. Ann. Mus. Civ. Stor. Nat. Giacomo Doria 68: 319-334

Tortonese E. 1956. Catalogo degli Echinodermi della collezione E. Tortonese. Ann. Mus. Civ. Stor. Nat. Giacomo Doria 69: 177-233.

Tortonese E. 1958. Il popolamento di Echinodermi nella zone profonde del Mediterraneo. Rapp. P. V. CIESM XIV 485-491.

Tortonese E. 1963. Note Sistematiche e Corologiche su alcuni echinodermi del Mediterraneo. Ann. Mus. Civ. Stor. Nat. Giacomo Doria 73: 282-296.

Tortonese E. 1965. Echinodermata. Fauna D'Italia. Edizioni Calderini, Bologna, $422 \mathrm{pp}$

Tortonese E. 1972. L'Echinofauna del piano batiale nel golfo di Genova. Ann. Mus. Civ. Stor. Nat. Giacomo Doria 204: 1-7.

Tortonese E. 1979. Review of the présent status of knowledge of the Mediterranean Echinoderms. Proc. Eur. Colloq. Echinoderms pp. 141-149.

Tyler P.A. 2003. The peripheral deep seas. In: Tyler P.A. (eds), Ecosystems of the World. Elsevier, Amsterdam, pp. 261-293.

Tyler P.A., Gage J.D. 1984. The reproductive biology of echinothuriid and cidarid sea urchins from the deep sea (Rockall Trough, North-East Atlantic Ocean). Mar. Biol 80: 63-74. http://dx.doi.org/10.1007/BF00393129

Uriz M.J., Rosell D. 1990. Sponges from bathyal depths (1000-1750 m) in the Western Mediterranean Sea. J. Nat. Hist. 24: 373-391. http://dx.doi.org/10.1080/00222939000770281

Villanueva R. 1992. Deep-sea cephalopods of the north-western Mediterranean: indications of up-slope ontogenetic migration in two bathybenthic species. J. Zool. 227: 267-276. http://dx.doi.org/10.1111/j.1469-7998.1992.tb04822.x 